Maurice A. Deane School of Law at Hofstra University Scholarly Commons at Hofstra Law

Hofstra Law Faculty Scholarship

2012

\title{
Not Guilty as Charged: The Myth of Mens Rea for Defendants with Mental Retardation
}

Elizabeth Nevins-Saunders

Maurice A. Deane School of Law at Hofstra University

Follow this and additional works at: https://scholarlycommons.law.hofstra.edu/faculty_scholarship

\section{Recommended Citation}

Elizabeth Nevins-Saunders, Not Guilty as Charged: The Myth of Mens Rea for Defendants with Mental Retardation, 45 U.C. Davis L. Rev. 1419 (2012)

Available at: https://scholarlycommons.law.hofstra.edu/faculty_scholarship/744

This Article is brought to you for free and open access by Scholarly Commons at Hofstra Law. It has been accepted for inclusion in Hofstra Law Faculty Scholarship by an authorized administrator of Scholarly Commons at Hofstra Law. For more information, please contact lawcls@hofstra.edu. 


\title{
Not Guilty as Charged: The Myth of Mens Rea for Defendants with Mental Retardation
}

\author{
Elizabeth Nevins-Saunders*
}

The notion that mens rea is an indicia of culpability runs deep in the American criminal law psyche. For most defendants, a finding that they had the requisite legal intent may be all we need to know to pronounce them morally culpable. This is because most defendants - those of average intelligence - enjoy a level of socialization, rationality, and agency sufficient to be aware of social norms, to make a choice to violate them or not, and to control their own impulses in doing so. But for defendants with mental retardation, the state-of-mind element fails to accurately signify a "guilty mind." Social science research makes clear (and existing neuroscience research seems to support) that these presumptions of consciousness, choice, and control do not apply to people with mental retardation. In essence, then, for this population, all offenses become strict liability offenses, where an intent inquiry becomes virtually meaningless.

While the criminal law does make some allowances for differences in cognitive capacity, it does so only in very limited circumstances, through the doctrines of competency, insanity, and diminished capacity. As a result, litigants must resort to crude perversions of justice to introduce evidence of mental retardation. Finding no valid policy or theoretical justification (apart from incapacitation) for this failure to adequately address the disjuncture between actual culpability and criminal liability, this Article offers a new approach to cases charging defendants with mental

* Copyright (c) 2012 Elizabeth Nevins-Saunders. Acting Assistant Professor of Lawyering, New York University School of Law. I am very grateful for helpful comments and conversations from Doug Husak, Austin Sarat, Rachel Barkow, Jim Jacobs, Randy Hertz, Robert Dinerstein, Tony Thompson, Erin Murphy, Adam Zimmerman, Jussi Tapani, Anita Wu, and the participants in the NYU Lawyering Scholarship Colloquium. Thanks are also due to NYU's Center for Research in Crime and Justice, which supported me during much of this project. Andrew T. Meyer provided truly phenomenal research assistance. 
retardation. Specifically, it proposes a new default rule, where nonviolent cases against them would be presumptively dismissed. More serious cases charging violent crimes could proceed to trial with the standard mens rea requirements, but would require that any sentence imposed be the least restrictive alternative necessary to accomplish an articulable sentencing goal. This proposal redresses a major flaw in current criminal law doctrine, one which unjustly permits a finding of guilty minds among defendants whose true culpability may not be presumed.

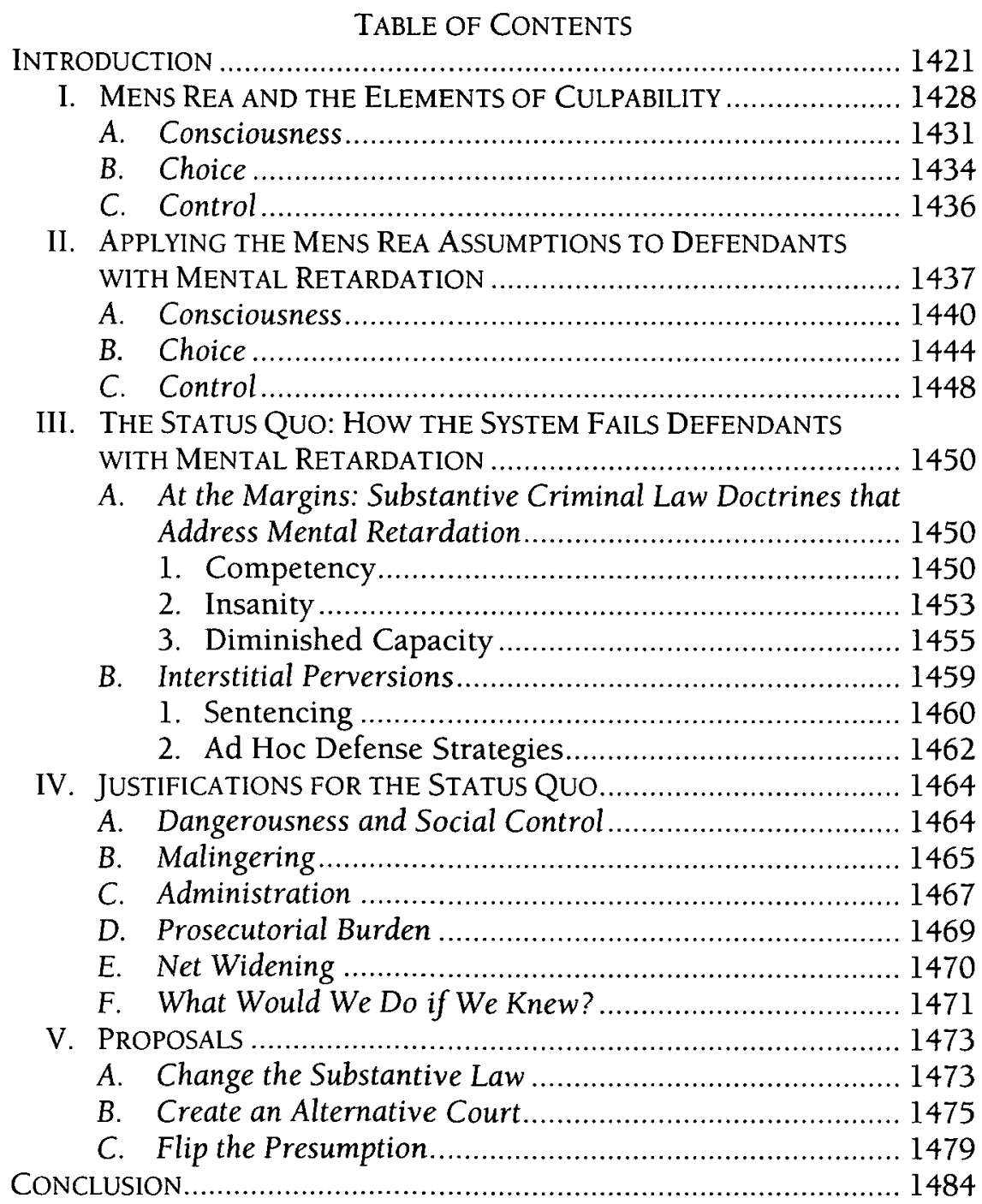




\section{INTRODUCTION}

It is no longer news that there is a significant and troubling overlap in the population of criminal defendants and those with mental health issues. $^{1}$ The recent proliferation of mental health courts, judicial panels, and media coverage demonstrates that, after decades of ignoring the issue, the criminal justice system - if not the criminal law - is finally beginning to address the particular concerns that this population poses to law enforcement, courts, and corrections agencies. ${ }^{2}$ People with mental retardation, ${ }^{3}$ however, have been largely overlooked in this wave of attention. ${ }^{4}$

Nonetheless, our prisons and jails are full of people with mental retardation. ${ }^{5}$ Definitions of mental retardation vary and are

1 It is estimated that over $5 \%$ of the US population has a serious mental illness. R.C. Kessler et al., The 12-Month Prevalence and Correlates of Serious Mental Illness (SMI), in Mental Health, United States 1996, 59, 63 (R.W. Manderscheid, ed., 1996). Among jail and prison populations, however, the figure is $16 \%$. PAULA $M$.

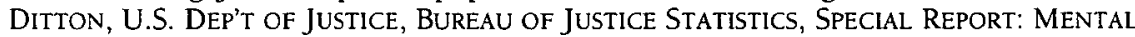
Health and Treatment of InMates and Probationers 3 (1999), available at http://bjs.ojp.usdoj.gov/content/pub/pdf/mhtip.pdf.

2 A decade ago, only a handful of mental health courts were in operation in the United States; by 2007, there were more than 175. CRIMINAL JUSTICE/MENTAL HEALTH Consensus Project, Council of State Gov'ts Justice Ctr., Mental Health Courts: A PRIMER FOR POLICYMAKERS AND PRACTITIONERS 1 (2008).

3 While the definition of mental retardation is the subject of much debate, it is typically considered an intellectual disability that (1) originates before age $18,(2)$ is characterized by significant limitations in intellectual functioning, and (3) is accompanied by significant adaptive functioning limitations in a range of every day social and practical skills. See Am. Ass'N ON Mental Retardation, Mental Retardation: Definition, Classification, and Systems of Support 36-37 (10th ed. 2002) [hereinafter 2002 AAMR ManUal]; AM. Psychiatric Ass'N, Diagnostic AND Statistical Manual of Mental Disorders 41 (4th ed., rev. vol. 2000) [hereinafter DSM-IV-TR].

4 For instance, a 2005 survey of 90 mental health courts (representing 80 percent of the known mental health courts at the time) found that just 16 percent would even accept clients with developmental disabilities. Criminal Justice/Mental Health Consensus Project, Council of State Gov'ts Justice Ctr., Mental Health Courts: A NATIONAL SNAPSHOT 3 (2005). More generally, a significant shortage of programs targeting this population persists despite the concerns of advocates. See generally, James W. Ellis \& Ruth A. Luckasson, Mentally Retarded Criminal Defendants, 53 GEO. WASH. L. REV. 4l4, 479-80 (1985) (finding insufficient mental retardation rehabilitation programs in prisons); Jessica Jones, Persons with Intellectual Disabilities in the Criminal Justice System: Review of Issues, 51 INT'L J. OfFENDER THERAPY \& COMP. CRIMINOLOGY 723, 729 (2007).

5 Most progressive advocates use the term "intellectual disabilities" instead of "mental retardation" because of the stigma, datedness, and general disfavor with which the term is viewed. See Robert L. Schalock et al., Perspectives: The Renaming of Mental Retardation: Understanding the Change to the Term Intellectual Disability, 45 
controversial. Experts generally agree, though, that it is a lifelong condition $^{6}$ which manifests before age 18 and is characterized by significant limitations in intellectual ${ }^{7}$ and adaptive functioning. ${ }^{8}$ While there is some dispute as to the precise rate at which this population is involved in the criminal justice system, ${ }^{9}$ there is no question that this group is heavily represented or even overrepresented. ${ }^{10}$ Moreover, a defendant with mental retardation tends to be subject to harsher treatment than one without such a condition at virtually every step of the criminal process: a defendant with mental retardation is more

INTELl. \& Developmental. Disabilities 116 (2007). The term "intellectual disability" or "ID" is defined as a person with "significant limitations both in intellectual functioning and in adaptive behavior as expressed in conceptual, social, and practical adaptive skills. This disability originates before age 18." Id. at 118 . Because the criminal law typically uses "mental retardation," however, this is the nomenclature I generally employ in this Article.

6 Cynthia J. Curry et al., Evaluation of Mental Retardation: Recommendations of a Consensus Conference, 72 AM. J. MED. GENETICS 468, 468 (1997).

7 Although the assessment of IQ is one of the most controversial aspects of the definition of mental retardation, its use persists, particularly as a necessary, but not sufficient, way to differentiate among levels of retardation. See 2002 AAMR MANUAL, supra note 3, at 25-27. According to the DSM-IV-TR, Mild Mental Retardation reflects an IQ level of 50-55 to approximately 70; Moderate Mental Retardation reflects an IQ level of 35-40 to 50-55; Severe Mental Retardation reflects an IQ level of 20-25 to 3540 , and Profound Retardation reflects an IQ level below 20-25. DSM-IV-TR, supra note 3 , at $41-42$.

8 Adaptive functioning "refers to how effectively individuals cope with common life demands and how well they meet the standards of personal independence" relative to their peers. See DSM-IV-TR, supra note 3, at 42.

9 There is no consensus as to the number of individuals in the criminal justice system who have some degree of mental retardation. One estimate suggests that least $2 \%$ and as many as $40 \%$ of offenders may have intellectual disabilities. Jones, supra note 4 , at 724 . There is not even consensus as to the proportion of people with intellectual disabilities among incarcerated populations, although a 1992 survey of state and federal prison administrators reported that approximately 4.2 percent of inmates were mentally retarded and an additional 10.7 percent had learning disabilities. Lewis Veneziano \& Carol Veneziano, Disabled Inmates, in ENCYCLOPEDIA OF AMERICAN Prisons 157, 159 tbl.2 (Marilyn D. McShane \& Frank P. Williams, Ill eds., 1996); see also Robert Dinerstein, The Criminal Justice System and Mental Retardation: Defendants and Victims, 97 AM. J. MENTAL ReTARDATION 715, 716 (1993) (book review) ("[T]here are virtually no reliable data on the number of inmates with mental retardation in local jails, where arrestees and those convicted of misdemeanors would normally be housed, let alone data on all arrestees ....").

10 Dorothy M. Griffiths, Peggy Taillon-Wasmund \& Debra Smith, Offenders Who Have a Developmental Disability, in DUAL DIAGNOSIS: AN INTRODUCTION TO THE MENTAL Health NeEds of Persons with Developmental Disabilities 387, 390 (Dorothy M. Griffiths et al. eds., 2002) (citation omitted) ("[P]eople with developmental disabilities are overrepresented in the criminal justice system, despite the fact that their crimes are of much less severity."). 
likely to be arrested, more likely to be held pending trial, more likely to be convicted, more likely to receive longer sentences, and more likely to be abused during incarceration. ${ }^{11}$ This treatment occurs despite the fact that social science and neuroscience research ${ }^{12}$ demonstrates - and the Supreme Court has acknowledged - that defendants with mental retardation are categorically less culpable than their peers of average intelligence. ${ }^{13}$ Far from a life preserver keeping this less blameworthy population above the swells of the criminal justice system, mental retardation seems more like an anchor.

Defendants with mental retardation become enmeshed in the criminal justice system in part because there are so few ways that the law even acknowledges their disability. Criminal law primarily addresses mental retardation or other differences in cognition through the competency and insanity doctrines. ${ }^{14}$ Because these are exit ramps from the criminal system (albeit likely on-ramps to the public mental health system), these routes are deliberately narrow, allowing passage only to the most extreme cases. ${ }^{15}$ In 2002, in Atkins v. Virginia, the

11 See Kenneth L. Appelbaum \& Paul S. Appelbaum, Criminal-Justice-Related Competencies in Defendants with Mental Retardation, 22 J. PSYCHIATRY \& L. 483, 486 (1994); Carry L. Reichard et al., Law School Curriculum: Does It Address the Needs of the Mentally Retarded Offender?, in THE RETARDED OFFENDER 226, 227 (M.B. Santamour $\&$ P.S. Watson eds., 1982); Salvador C. Uy, From the Ashes of Penry v. Lynaugh: The Diminished Intent Approach to the Trial and Sentencing of the Mentally Retarded Offender, 21 COLUM. HuM. RTS. L. ReV. 565, 570 (1990).

12 While the psychological and other social science research on people with mental retardation is extensive, the neuroscience research is significantly more limited and much less conclusive. See infra Part II.

13 Atkins v. Virginia, 536 U.S. 304, 316 (2002); see also Uy, supra note 11.

14 See Donald H. J. Hermann, et al., Sentencing of the Mentally Retarded Criminal Defendant, 41 ARK. L. REV. 765, 768 (1988) (describing contemporary criminal justice concerns about "a mentally subnormal defendant who is found unfit to stand trial or criminally nonresponsible because of mental retardation"); see also Ellis \& Luckasson, supra note 4 , at 453 ("[T]he public has fixed its attention on the insanity defense" but it is "certainly correct" to call competence to stand trial "the most significant mental health inquiry pursued in the system of criminal law." (citing ALAN STONE, MENTAL HEALTH and LaW: A System in TRansition 200 (1975))).

15 The insanity defense is raised in less than one percent of felony cases and is successful in just a fraction of those instances. MiCHAEL PERLiN, THE JURISPRUdenCE OF tHe InSANITY Defense 108 (Carolina Academic Press 1994); see also Linda C. Fentiman, Whose Right Is It Anyway?: Rethinking Competency to Stand Trial in Light of the Synthetically Sane Insanity Defendant, 40 U. MiAMI L. REV. 1109, 1112 n.6 (citing commentator's statement that "the incidence of cases in which the insanity defense is raised is lower than the annual incidence of poisonous snakebites on the island of Manhattan"). An estimated 2-8\% of felony defendants are referred for competency screenings. Jodi L. Viljoen \& Patricia A. Zapf, Fitness to Stand Trial Evaluations: A Comparison of Referred and Non-Referred Defendants, 1 INT'L. J. FORENSIC MENTAL 
Supreme Court announced the only current categorical rule addressing defendants with mental retardation: they cannot be executed.$^{16}$ More typically, courts only consider the issue of a person's mental retardation through isolated pockets of substantive or procedural doctrine. ${ }^{17}$

With few formal doctrinal tools available, players within the system - prosecutors, defense counsel, and judges - have two choices. First, they can resort to an array of stopgap measures designed to prevent injustices from occurring. Among these is the use of discretion, primarily in sentencing. ${ }^{18}$ Second, they can turn a collective blind eye to the issue, pretending there is no difference between an average twenty year-old defendant and one who functions more like an eight year-old. ${ }^{19}$

However, both choices can pervert just outcomes. The failure to meaningfully and systematically address differences in cognitive capacity (apart from competence or sanity) has repercussions not only for people within the population, but also for the integrity of the system itself. We should not rely on the discretion of gatekeepers to determine which cases merit prosecution against defendants with mental retardation. Sentence mitigation is an inappropriate substitute

HeALTH 127, 127 (2002). The vast majority of those evaluated - as many as $96 \%$ in some jurisdictions - are found to be competent. See Bruce J. Winick, Criminal Law: Reforming Incompetency to Stand Trial and Plead Guilty: A Restated Proposal and a Response to Professor Bonnie, 85 J. CRIM. L. \& CRIMINOlogy 571, 578 (1995). As one scholar put it, "The threshold of competence for defendants with mental retardation is set relatively low in practice, and a substantial number of these defendants are, at best, marginally competent." Richard J. Bonnie, The Competence of Criminal Defendants with Mental Retardation to Participate in Their Own Defense, 81 J. CRIM. L. \& CRIMINOLOGY $419,422-23$ (1990).

${ }_{16}$ See infra Part lil.B.

17 For example, mental retardation may be a factor in assessing a waiver of rights or the voluntariness of consent. See Colorado v. Connelly, 479 U.S. 157, 164 (1986); Schneckloth v. Bustamonte, 412 U.S. 218, 226-27 (1973). It may also be part of a socalled diminished capacity "defense," a legal doctrine most notable for its very limited applicability. See infra Part III.A.3.

18 See, e.g., Sandra Anderson Garcia \& Holly Villareal Steele, Mentally Retarded Offenders in the Criminal Justice and Mental Retardation Services Systems in Florida: Philosophical, Placement, and Treatment Issues, 41 ARK. L. REV. 809, 832-33 (1988) (citing studies supporting claim that courts use discretion to consider mental retardation at sentencing "even when a mental defense to a charge is not available"); see also Ballou v. Booker, 777 F.2d 910, 917 (4th Cir. 1985).

19 See Reichard et al., supra note 11, at 226, 227 (“'[A] ttorneys continue to defend and prosecute retarded persons and judges continue to sentence them with little or no recognition of the role of retardation in a defendant's case." (quoting R.C. Allen, Toward an Exceptional Offenders' Court, in 4 Mental RETARDATION 1, 3-7 (1966))); see also Bonnie, supra note 15, at 429. 
for a lack of doctrinal tools addressing mental retardation. Novel defense strategies that encourage juror nullification should not be the only vehicle through which fact-finders can hear evidence of a defendant's mental retardation. And, of course, simply disregarding the difference that mental retardation makes does not make that difference - or the unjustness of punishing such an undeserving defendant - disappear.

Given the disjuncture between actual culpability and criminal liability for defendants with mental retardation, this Article rejects the premise that mens rea is a fair indicator of culpability for these defendants. ${ }^{20}$ I propose a new approach, which flips the assumption of blameworthiness for this population. In my proposal, non-violent offenses would be presumptively dismissed, and violent offenses would be limited to the least restrictive sentencing alternative that could satisfy specific goals of punishment.

While scholars in other disciplines have focused on the challenges that defendants with mental illnesses encounter in and pose to the criminal justice system, few legal academics have addressed concerns specific to defendants with mental retardation outside the death penalty context. Moreover, much like criminal law, legal scholars approaching the issue tend to focus on just one aspect of the issue waiver of rights, competency, sentencing ${ }^{21}$ - or briefly address a range of such issues, often from a practice-oriented perspective. ${ }^{22}$ Virtually no one offers a comprehensive proposal specific to this population, much less one that addresses the issue of culpability at the outset of a case. Because the problems relating to defendants with mental retardation are so systemic and because a piecemeal solution

20 By "mens rea" (also called scienter, state-of-mind, mental state, or criminal intent), I mean what Dressler calls "narrow" or "elemental" mens rea: the state of mind description that is included as an element in the definition of a criminal offense. What I refer to interchangeably as "culpability" or "blameworthiness" is akin to Dressler's "broad" mens rea, a concept of moral responsibility or blameworthiness. See Joshua DRessler, Cases and Materials on CRiminal LaW 118-19 (5th ed. 2009) [hereinafter CASES].

21 See, e.g., Bonnie, supra note 15 (addressing competency of defendants with mental retardation); Morgan Cloud et al., Words Without Meaning: The Constitution, Confessions, and Mentally Retarded Suspects, 69 U. CHI. L. REV. 495, 514 (2002) (addressing confessions); Hermann et al., supra note 14 (addressing sentencing).

22 See, e.g., Ronald W. Conley \& Ruth Luckasson, The CRIminal Justice System and Mental Retardation: Defendants and Victims 55, 58 (George N. Bouthilet ed., 1992) (addressing a range of issues related to representation of criminal defendants with mental retardation); Diane Courselle et al., Suspects, Defendants, and Offenders with Mental Retardation in Wyoming, 1 WYO. L. REV. 1 (2001) (same); Ellis \& Luckasson, supra note 4 (same). 
- even one which has more "pieces" than our current approach — is ultimately insufficient, we need a broad response, one which applies to nearly all criminal cases.

This Article proceeds in five parts. Part I analyzes the meaning and locus of culpability in criminal law. Scholars and courts typically agree that, in our system of justice, people should only be punished or held accountable to the extent that they are blameworthy. ${ }^{23}$ Mens rea is the initial signifier of moral blameworthiness, and it is critical to the difference between addressing wrongs through criminal law and addressing them through civil law. ${ }^{24}$ But, what do we mean when we describe a person as culpable? At a minimum, culpability requires a level of socialization, rationality, and agency sufficient to be aware of social norms, to make a choice to violate them, and to control one's actions in so doing. ${ }^{25}$ To say that a person has criminal intent, then, implies that he has these capacities.

Part II argues that mens rea fails to capture the moral culpability of most people with mental retardation. In particular, the psychosocial and existing neuroscience literature reveals that people with mental retardation do not typically demonstrate the consciousness, choice, and control that underlie notions of blameworthiness. For many people with mental retardation, all offenses become strict liability offenses, where intent is irrelevant to the analysis of guilt. Rather than serving as a narrow exception to the doctrine of mens rea, for defendants with mental retardation, strict liability swallows the rule. A real investigation into the state of mind and conduct of defendants with mental retardation would be forced to reckon with features common to this population, such as social isolation, low intellectual sophistication, high vulnerability to manipulation, and significantly impaired impulse control.

Part III considers, and rejects as insufficient, ways in which substantive criminal law doctrine currently seeks to account for the diminished culpability of defendants with mental retardation. This includes the very restricted doctrines of competency, insanity, and diminished capacity. The law's inattentiveness to mental retardation in adults in determining their guilt or innocence not only skews outcomes for particular individuals, but also distorts and undermines the integrity of the criminal law itself.

${ }^{23}$ See generally infra Part I.

24 Peter Arenella, Convicting the Morally Blameless: Reassessing the Relationship Between Legal and Moral Accountability, 39 UCLA L. REV. 1511, 1527 (1992) [hereinafter Convicting].

25 See infra note 31 and accompanying text. 
Part IV explores the potential justifications for limiting our response to this culpability gap and forgoing a more meaningful intent analysis, such as administrative efficiency and public safety. However, 1 argue that these concerns do not outweigh the problem of implying - and punishing - moral responsibility where none exists, particularly for nonviolent offenses.

Accordingly, in Part V, I propose a bifurcated approach to the prosecution of defendants with mental retardation. For non-violent offenses, a presumption of dismissal would apply. In more serious cases, although a typical prosecution could proceed, any sentence would be limited to the least restrictive alternative. This proposal addresses the problem at its core, at the outset of the criminal process, while still accommodating legitimate safety concerns.

It is worth noting upfront what this Article will not address. While people with other cognitive disorders, mental illnesses, or substance abuse issues may face many of the same issues as defendants with mental retardation, they are not the subject of this Article. The criminal law does not recognize these groups in the same way it has already recognized defendants with mental retardation. ${ }^{26}$ Moreover, too much variation exists in diagnoses, symptoms, treatments, ${ }^{27}$ and possibly even blameworthiness ${ }^{28}$ to assume that the same theoretical framework should equally apply to these other classes of defendants.

Ultimately, I leave to others the task of finding commonalities - or even differences - which might suggest additional classes of defendants lack the culpability that the criminal law may attribute to them. A wider movement toward a more meaningful intent inquiry could bring us closer to legitimating the claim that criminal law only punishes those with a guilty mind.

26 The most obvious such distinction is the per se exclusion of people with mental retardation from the death penalty. See Atkins v. Virginia, 536 U.S. 304, 316 (2002).

27 For instance, while many individuals with mental illnesses can take antipsychotic or other medication to minimize or fully address their symptoms, there is no medication that people with mental retardation can take to ameliorate their disability. See Part IV.E for more on the distinction between defendants with mental retardation and others groups.

28 Some might argue that a culpable choice - to reject available pharmacological treatment for people with mental illnesses or to imbibe drugs or alcohol for people with substance addictions - renders any resulting criminal conduct among these cohorts blameworthy, even if such individuals otherwise may not have fully intended their actions. See infra note 249 and accompanying text for more on this debate. 


\section{MENS REA AND THE ELEMENTS OF CULPABILITY}

The American system of criminal law is inextricably bound up in issues of culpability and blameworthiness. ${ }^{29}$ It is virtually undisputed that the law should not touch innocent conduct, but rather should punish only culpable action. ${ }^{30}$ As set forth below, both historically and currently, the criminal law initially situates that culpability in the element of mens rea. ${ }^{31}$ This section breaks down the assumptions embedded in a finding of mens rea to help explain why such a conceptual linkage is possible. In particular, asserting that a person has the requisite intent to commit an offense suggests that the individual has at least three discrete capacities:

A. Consciousness: subjective awareness and rational understanding of social norms and potential risks (to others' interests);

B. Choice: ability to rationally consider those norms and determine whether to abide by or violate them, as well as to be fully aware of one's actions; and

C. Control: the power to deliberately violate social norms and exercise independent judgment.

Although the law may not have explicitly reflected the distinction until the tenth century, ${ }^{32}$ mens rea has long marked the dividing line between accidental and intentional harms; ${ }^{33}$ between the law's selective power to punish and state-inflicted vengeance for conduct

29 See generally Paul H. Robinson \& Michael T. Cahill, LaW Without Justice (2006) (focusing on "desert" or "justice" as central justification for criminal justice system).

30 See, e.g., Hermann et al., supra note 14, at 802 ("[D]efendant lacked the culpability which is which is a precondition to punishment."); R. George Wright, The Progressive Logic of Criminal Responsibility and the Circumstances of the Most Deprived, 43 CATH. U. L. REV. 459, 459-60 (1994) ("There is remarkable agreement that in general, the legal system must not impose punishment unless the defendant is blameworthy or bears moral responsibility for her act.").

31 See Stephen F. Smith, Proportional Mens Rea, 46 AM. CRIM. L. Rev. 127, 127 (2009) (arguing that mens rea is meant to demonstrate at least "modicum of moral blameworthiness as a precondition to punishment").

32 Paul H. Robinson, A Brief History of Distinctions in Criminal Culpability, 31 HASTINGS L.J. 815, 830 (1980).

33 As Holmes explained with regard to early legal claims being limited to harms intentionally inflicted, "Even a dog distinguishes between being stumbled over and being kicked." Oliver Wendell Holmes, The COMmon Law 3 (Dover Publ'ns 1991) (1881). 
with harmful consequences; ${ }^{34}$ and between criminal law and a civil system seeking to protect individuals without regard to morality. ${ }^{35}$ Mens rea is now such a defining feature of criminal law that every first-year law student learns that a "guilty act" (actus reus) is usually criminal only if accompanied by a "guilty mind" (mens rea). ${ }^{36}$

This connection between mens rea and culpability persists today. Stuart Green defines culpability as "the moral value attributed to a defendant's state of mind during the commission of a crime" or something which "reflects the degree to which an individual offender is blameworthy or responsible or can be held accountable." ${ }^{3 i}$ This definition demonstrates the near perfect overlap between these two concepts. Indeed, the Model Penal Code titles its section on mens rea "General Requirements of Culpability" 38 and mandates that every criminal offense include a culpability element unless a legislature clearly and deliberately indicates its intent to do otherwise. ${ }^{39}$

State and federal criminal codes also continue to include proof of mental state among the required elements defining the vast majority of criminal offenses, particularly non-regulatory crimes. ${ }^{40}$ While refusing to hold that proof of some mens rea is a constitutional due process

34 See, e.g., Martin R. Gardner, The Mens Rea Enigma: Observations on the Role of Motive in the Criminal Law Past and Present, 1993 UTAH L. REV. 635, 652 (observing that when law historically focused on "compensating and buying off the feud" between parties, it "likely paid little attention to niceties of culpability"); Robinson, supra note 32, at 823-24 (arguing that, historically, liability was based on instinctive impulse to exact revenge on apparent source of evil result).

35 See Robinson, supra note 32 , at 816 n.9 (citing A. KIRALFY, POTTER's OUTLINES OF ENGlish LeGAL. History 156, 158, 163-65 (5th ed. 1958)); see also Arenella, Convicting, supra note 24 , at 1527.

36 See Jeremy M. Miller, Mens Rea Quagmire: The Conscience or Consciousness of the Criminal Law?, 29 W. ST. U. L. REV. 21, 21 (2002) ("Crimes require a mental state or 'mens rea' element. Everyone in law understands this." (emphasis added)).

37 Stuart P. Green, Why it's a Crime to Tear the Tag off a Mattress: Overcriminalization and the Moral Content of Regulatory Offenses, 46 EMORY L.J. 1533, 1547-48 (1997).

38 Model Penal Code $\$ 2.02$ (West 2010).

39 See Model Penal Code $\S \S 2.02(1), 2.05(1)$ (b) (1985); Paul H. Robinson \& Markus Dirk Dubber, AN Introduction to the Model Penal Code 12-13, available at http://www.law.upenn.edu/fac/phrobins/intromodpencode.pdf (explaining intent of Code's authors to require clear legislative purpose excluding culpability element).

40 Although legislatures may choose to enact strict liability crimes with no mens rea requirement, they typically do so primarily for so-called "public welfare" or regulatory offenses. See Francis B. Sayre, Public Welfare Offenses, 33 Colum. L. REV. 55,56 n.5, $72-73$ (1933) (coining term "public welfare offenses" and cataloguing examples of such low-level, strict-liability crimes). More serious, mala in se offenses (those that are considered inherently wrong or immoral), typically require some proof of the defendant's moral culpability. See Arenella, Convicting, supra note 24, at 1527. 
mandate, the Supreme Court has made clear that a "vicious will" element in any offense definition is no "provincial or transient notion." ${ }^{\text {11 }}$ Scholars, too, have exhorted the importance of only punishing those who are truly blameworthy and, accordingly, "deserving" of public opprobrium. ${ }^{42}$ Offenses that are strict liability requiring an actus reus, but no mens rea - have been routinely criticized in legal scholarship. ${ }^{43}$

Despite this context, some have pointed more recently to an evisceration of the intent element, or at least acknowledged that when it comes to considering intent, most of the heavy lifting occurs in sentencing. ${ }^{44}$ Indeed, at the sentencing stage, a judge or jury is compelled to assess not only the offense committed, but also aggravating and mitigating factors about both the offense and the offender. In a wide-ranging inquiry, bounded only by statutory sentencing ranges, the decision-maker may well take into account the defendant's diminished culpability with mental retardation. But, at best, this may be only one of the many factors that the judge or jury weighs. ${ }^{45}$ An individual's culpability - or, more pointedly, his lack thereof - may also be manifest in his affirmative defense to a charge. ${ }^{46}$

41 Morissette v. United States, 342 U.S. 246, 251 (1952).

42 See, e.g., Smith, supra note 31 , at 127 (arguing that federal mens rea doctrine is designed to exempt all "innocent" or "morally blameless" conduct from punishment and should also be used to prevent disproportionate punishment).

${ }_{43}$ See, e.g., Sanford H. Kadish, Fifty Years of Criminal Law: An Opinionated Review, 87 CALIF. L. REV. 943, 954-59 (1999) (critiquing trend toward "liability without fault"); Laurie L. Levenson, Good Faith Defenses: Reshaping Strict Liability Crimes, 78 CORNELL L. REV. 401, 425-28 (1993) (outlining retributivist and utilitarian objections to strict liability); Sayre, supra note 40 , at $78-83$ (arguing that strict liability should be limited to offenses with "really slight" penalties).

44 See, e.g., Green, supra note 37, at 1548 ("Although the elimination or diminution of the criminal intent requirement has become fairly commonplace (particularly in the regulatory area), this diminution is nevertheless viewed by most commentators as inconsistent with the moral underpinnings of the criminal law."); $c f$. Doug Husak, The Costs to Criminal Theory of Supposing that Intentions are Irrelevant to Permissibility, 3 CRIM. L. \& PHIL. 51, 52-54 (2008) (critiquing view of many moral philosophers that intention is "irrelevant to permissibility," and asserting difficulty inherent in reconciling such a view with substantive criminal law).

${ }^{45}$ In recent decades, the Federal Sentencing Guidelines have aimed to reduce judicial discretion in sentencing. See Charles J. Ogletree, Jr., The Death of Discretion? Reflections on the Federal Sentencing Guidelines, 101 HARv. L. REv. 1938, 1940-44, 1946-47 (1988); see also Gardner, supra note 34, at 747-48 (arguing that individualized determinations of defendant's "evil motive," background, and character is open-ended speculation better suited to competence of judges engaged in sentencing after determination of guilt has been made).

${ }^{46}$ See Gardner, supra note 34, at 737-42. 
Compared with both of these facets of criminal law, mens rea tends to focus more on the offender than the offense and is a more discrete inquiry than sentencing. ${ }^{47}$

While mens rea may not be a precise index for the extent of blameworthiness or the punishment to impose on a particular occasion, it does indicate a threshold level of culpability ${ }^{48}$ Further, the theory and history underlying mens rea, and the credibility of our justice system, demonstrate the import of establishing some level of blameworthiness as part of the case-in-chief, long before sentencing. As the Model Penal Code comments suggest with regard to the Code's articulation of mens rea standards (and its implicit critique of strict liability), "crime does and should mean condemnation, and no court should have to pass that judgment unless it can declare that the defendant's act was culpable." 49

Consistent with the purpose of mens rea as a measure of culpability, the mens rea inquiry should be meaningful. For most defendants, mens rea does indeed signify the "moral underpinnings of the criminal law," because its shorthand presumes a number of capacities critical to moral (or immoral) decision-making on the part of a defendant..$^{50} \mathrm{I}$ refer to these as (A) consciousness, (B) choice, and (C) control, and address each in turn below.

\section{A. Consciousness}

Two types of consciousness comprise the first part of mens rea. The first is awareness of a legal or moral norm..$^{51}$ The second is awareness of the likely consequences of certain conduct - that is, how one's behavior may affect or harm another person, object, or entity. ${ }^{52}$ Each of these interpretations of consciousness requires underlying cognitive

47 See Green, supra note 37 , at 1548 ("Culpability reflects the degree to which an individual offender is blameworthy or responsible or can be held accountable. It characterizes the actor, rather than the act and its consequences.").

48 See Albert Levitt, The Origin of the Doctrine of Mens Rea, 17 U. ILL. L. REv. 117, 136 (1922) (noting "[i]f the mind of the criminal or sinner is guilty, the punishment is greater than if his mind is not guilty"); see also Sanford H. Kadish, Excusing Crime, 75 CALif. L. ReV. 257, 260-61 (1987)

49 MODEl PenAl CODE \& 2.05 cmts. at 283 (1985) (explaining reason for rule that non-intent/strict liability offenses should typically only be considered non-criminal violations).

50 Green, supra note 37, at 1547-48.

51 See Herbert L. Packer, Mens Rea and the Supreme Court, 1962 SUP. CT. Rev. 107, 108 (1962).

52 See infra notes 60-61 and accompanying text (elaborating on this form of consciousness). 
or social skills and the criminal law presumes adults have a certain level of competency in these areas. ${ }^{53}$ Taking the example of a defendant charged with arson, I demonstrate how each of these types of consciousness comes into play. ${ }^{54}$

First, while ignorance of the law is famously no excuse for failing to comply with its terms, a person must have some awareness or "notice" 55 of the social and moral codes to which he is subject before he may be considered blameworthy for violating them. Some theorists note, "For norms to have meaning, the actor must be able to appreciate the prohibition." ${ }^{56}$ Rather than requiring that individuals learn every code in the codebook, this element assumes that individuals are at least familiar with principles of social engagement. ${ }^{57}$ For our model defendant, such consciousness includes a general understanding that deliberately setting fire to other people's possessions is normatively "wrong" - morally, socially, and legally. The individual may not understand that a law exists forbidding the behavior or even why it is impermissible; but he should nonetheless perceive it to be a punishable wrong.

Appreciating norms like this draws on particular cognitive and social skills. For instance, an individual would need to understand what it means to live in a culture shaped by norms and the importance of abiding by norms generally. More specifically, she would need to be able to learn, appreciate, and remember particular social mores and expectations ${ }^{58}$ In addition to cognitive skills required to obtain such

53 The exceptions, of course, are adults who have been found not competent for trial. See infra Part III.A.1.

54 Under the Model Penal Code, a person may be guilty of arson if he "purposely starts a fire ... whether on his own property or another's, and thereby recklessly: (a) places another person in danger of death or bodily injury; or (b) places a building or occupied structure of another in danger of damage or destruction." MODEL PENAL CODE \& 220.1(2) (1980).

55 It is, in part, this lack of notice that some point to in criticizing strict liability offenses. See Elizabeth Nevins-Saunders, Incomprehensible Crimes: Defendants with Mental Retardation Charged with Statutory Rape, 85 N.Y.U. L. REV. 1067, 1078-82 (2010); see also Lambert v. California, 355 U.S. 225, 228-30 (1957) (holding that defendant could not be convicted for failure to register as felon where there was no evidence of actual or constructive notice of statutory requirement to do so).

56 Larry alexander \& Kimberly Kessler ferzan, Crime and Culpability: A THEORY OF CRIMINAL LAW 17 (2009).

57 See Robinson, supra note 32, at 819-20.

58 See Theodore Y. Blumoff, The Problems with Blaming, in LAW, MIND, AND BRAIN 127, 131-32 \& nn.14-17 (Michael Freeman \& Oliver R. Goodenough, eds., 2009) (suggesting higher level cognitive and volitional capacities required for making morally responsible or at least "prudent" decisions). 
information (potentially including literacy, ability to comprehend verbal instructions or ideas, and memory), a person likely needs access to and participation in social networks that can transmit and reinforce specific norms. $^{59}$

Apart from understanding general or specific social expectations, individuals should also be able "to comprehend the consequences that their actions will have on others" before they may be subject to punishment. ${ }^{60}$ This second type of consciousness means that, whether a person knows there is a rule against setting fires or that setting fire to another person's property is morally wrong, the law expects all adults to appreciate the likely injury they would cause by lighting matches in a neighbor's garage and setting them atop an old collection of comic books. Divorced from specific rules, this is the most common type of awareness enshrined in the criminal law. The Model Penal Code, for instance, focuses its culpability element on an awareness of risk or danger that a particular outcome will likely occur. ${ }^{61}$

Again, such awareness assumes particular skills on the part of the defendant. Cognitively, an individual would need to understand cause and effect across a wide range of substantive areas. Applied to our arson example, this means that the defendant would need to know both what he is doing (lighting a match) and the probable effect of lighting that match near the comic books (matches can create a fire; dry paper can stoke flames; a small fire can grow into a big one; fire can permanently destroy a building or other property; a person may be in or near a garage attached to a home; etc.).

There is also an empathetic component to this kind of consciousness. The notion of "harm" implies an awareness of others' interests and how one's own actions might affect another person, object, or entity. Closely tied to a consciousness of social norms, this form of awareness could add emotional content to a basic understanding of cause and effect (burning someone's stuff is not just

59 Paul H. Robinson et al., The Disutility of Injustice, 85 N.Y.U. L. REv. 1940, 1996 (2010) (describing utilitarian theory that legal norms are transmitted and reinforced through social networks).

60 AleXANDER \& FERZAN, supra note 56, at 17 ("[A]ctors must have substantial capacity to empathize with other human beings and affectively to comprehend the consequences that their actions will have on others before they can rightly be said to violate a moral or legal norm.").

61 Specifically, the Code's culpability elements focus on awareness of risk of harm to another. MODEL PENAL CODE \& 2.02(2) (1985); see also Robinson, supra note 32, at $816-17,819-20$ (explaining that conduct is "blameworthy" in the view of the Model Penal Code when individual engages in conduct and is aware or should be aware of its harmful consequences or risk thereof). 
against the rules, it is also likely to hurt someone) and a normative judgment (that effect on someone else - the harm - is a bad thing). Thus, even the baseline expectations of consciousness implicate a relatively high order of cognitive and social development.

\section{B. Choice}

Once a person appreciates the norms (or risk of harm) against which his conduct is measured, the individual must rationally evaluate the norm and the costs and benefits of violating it. " $[\mathrm{C}]$ riminal law presupposes that actors are rational actors who are capable of using reason to guide their conduct. It also assumes that actors have the capacity for self-reflection." ${ }^{62}$ Implicit in this ability is the capacity to act independently, without undue influence from others. While there is a rather thin line between what I call "consciousness" and what I call "choice," choice reflects the deliberation and decision-making that occurs, at least in part, based on a particular consciousness or understanding of rules and conventions. Choice designates the intentional decision to comply with or disregard social and legal norms, as well as the analytic process which precedes that decision. The decision not to comply is, effectively, criminal intent, and it explains why others refer to mens rea as "the mental state of defiance." 63

The capacity to choose whether to undertake a particular course of conduct is a quality that many scholars focus on when they argue that mens rea is determinative of moral blameworthiness. In H.L.A. Hart's terms, for instance, having this capacity is what defines a "choosing being," a status where people are held accountable for their choices and conduct. ${ }^{64}$ Such a theory of individual accountability only makes moral sense if the individual has, indeed, made a conscious, independent choice. ${ }^{65}$

62 ALEXANDER \& FERZAN, supra note 56, at 17.

63 Green, supra note 37, at 1548 n.29 (citing Jerome HALl, PRINCIPLES OF CRIMINAL LAW 281-86 (1947)); see also Samuel H. Pillsbury, The Meaning of Deserved Punishment: An Essay on Choice, Character, and Responsibility, 67 IND. L.J. 719, 744 n.95 (1992) (citing Jean Hampton, Mens Rea, in CRIME, CulPability AND REMEDY 1 (1990)) (referring to "criminal intentionality as a kind of defiance").

64 H.L.A. HART, PUNISHMENT AND ResPonsibility 49 (1968); see also AleXANDER \& FERZAN, supra note 56 , at 55 (stating that without choice, there is no responsibility); Claire Finkelstein, The Morality of Criminal Law: A Symposium in Honor of Professor Sandy Kadish: The Inefficiency of Mens Rea, 88 CALIF. L. REV. 895, 895 (2000) (discussing Kadish's theory of criminal law as mechanism for ascribing responsibility and assigning blame).

65 See Francis Bowes Sayre, Mens Rea, 45 HARV. L. REV. 974, 1004, 1013 (1932) 
Choice arguably involves a higher level of cognitive ability and psychosocial skills than consciousness of norms. In their work with adolescents, psychologists Elizabeth Cauffman and Laurence Steinberg propose a helpful model of psychosocial factors that affect decisionmaking, including (1) responsibility, (2) perspective, and (3) temperance.$^{66}$ Although I consider temperance in greater detail in the context of "control" below, responsibility and perspective are necessary skills for thoughtful decision-making.

Some examples of cognitive skills that provide a foundation for decision-making might include use of logic, comprehension of certain facts (such as the relationship between cause and effect), and ability to weigh costs and benefits. ${ }^{67}$ At the same time, psychosocial capacities underlying responsibility include self-reliance, clarity of identity, selfesteem, independence, and work orientation (pride in the successful completion of tasks) ${ }^{68}$ Perspective requires the ability to consider situations from different viewpoints and place them in broader social and temporal contexts. This includes the ability to see short and long term consequences and to take another person's perspectives into account. ${ }^{69}$

Choice also suggests that a person acts voluntarily, and not from the coercion, manipulation or compulsion of another. In extreme cases, affirmative defenses, such as self-defense, necessity, and duress may preclude finding criminal liability on these grounds ${ }^{70}$ However, the baseline legal presumption is that defendants that engage in certain

("[W]ithout a free exercise of choice one can not be said to have a guilty mind.").

${ }^{66}$ Elizabeth Cauffman \& Laurence Steinberg, (Im)maturity of Judgment in Adolescence: Why Adolescents May Be Less Culpable Than Adults, 18 BEHAV. SCI. \& L. 741,745 (2000) ("These categories are not mutually exclusive, nor are they without some cognitive elements. The ability to appreciate the long-term consequences of an action, for example, is an important element of perspective, but requires the cognitive ability to weigh risks and benefits, and is related to the ability to forgo immediate gratification, which is an element of temperance.").

67 See id., at 743-44; Lita Furby \& Ruth Beyth-Marom, Risk Taking in Adolescence: A Decision-Making Perspective, 12 Developmental Rev. 1, 11 (1992) (including ability to generate options and assess value and probability of those options among steps in normative model of decision-making); see also Marilyn Jacobs Quadrel, Baruch Fischhoff \& Wendy Davis, Adolescent (In)vulnerability, 48 AM. PsychOlOGIST 102, 104 (1993) (discussing misunderstanding of facts as partial justification for teen risktaking behavior). While these studies focused on adolescents, they found no major cognitive differences between adults and teenagers, at least for those fifteen and older.

68 Cauffman \& Steinberg, supra note 66 , at 747-48.

69 See id. at 745.

70 See Steven J. Mulroy, The Duress Defense's Uncharted Terrain: Applying it to Murder, Felony Murder, and the Mentally Retarded Defendant, 43 SAN DIEGO L. REV. 159, 162-63 (2006). 
conduct with the required mens rea have the moral and intellectual agency sufficient to hold them responsible for their behavior. ${ }^{71}$

\section{Control}

Finally, a truly culpable person not only chooses to behave in a certain anti-social way, but also executes that decision with intention. More than just engaging in the conduct itself, the control element of mens rea refers to the state of mind underlying the move from thought to action, so that the action is deliberate. Criminal law requires "a level of socialization and, except for those who fit extreme and narrowly defined exceptions such as the insanity defense, a level of intelligence, rationality, and capacity to act otherwise." ${ }^{72}$ Therefore, punishable conduct cannot be accidental, inadvertent, or arising from an impulse that the defendant cannot control. In Cauffman and Steinberg's terminology, this aspect of control is "temperance," a term which represents a person's impulse control, ability to evaluate situations before acting, and self-restraint from aggressive behavior. ${ }^{73}$ The Supreme Court has also linked self-control to culpability, finding that an inability to control one's actions can make a person less deserving of punishment. ${ }^{74}$

While it is possible, and important, to unpack the content and capacities which underlie mens rea, it is also risky. In exposing the gravity of the load we ask mens rea to bear in contrast to the ease with which it is typically dispatched in criminal cases, we may call into question more broadly the assumption of culpability it is meant to signify. ${ }^{75}$ Some scholars critique criminal law's assignment of blame, charging that it is based on a relatively flimsy account of moral agency. ${ }^{76}$ Such a challenge to mens rea and culpability generally is, however, beyond the scope of this Article. In fact, I assume that the law's basic assumptions about intelligence, rationality, and capacity to

7 See Arenella, Convicting, supra note 24, at 1522-23.

72 Peter W. Low, The Model Penal Code, The Common Law, and Mistakes of Fact: Recklessness, Negligence, or Strict Liability?, 19 RUTGERS L.J. 539, 548 (1988) (emphasis added).

${ }^{73}$ Cauffman \& Steinberg, supra note 66, at $748-49$ (describing psychological testing measuring "impulse control" and "suppression of aggression" in teenagers versus adults).

${ }^{74}$ See, e.g., Graham v. Florida, 130 S. Ct. 2011, 2026 (2010) (citing lack of behavioral control as factor leading to diminished culpability among juveniles).

${ }^{75}$ Cf. Smith, supra note 31, at 127 (referring to "traditional role" of mens rea as means of exempting all morally blameless conduct from criminal liability).

76 Arenella, Convicting, supra note 24, at 1610. 
act (or refrain from acting) may be borne out in the population generally, even if such attributes "simply may not in fact be true of a given offender." 77 Yet, as I argue in the next Part, these assumptions are ill-founded across the class of defendants with mental retardation.

\section{APPLYing THE MENS REA ASSUMPTIONS to DEFENDANTS WITH MENTAL RETARDATION}

Having broken down the meaning of culpability and the constituent parts of mens rea in Part I, this Part considers whether people with mental retardation are truly culpable, even where they fail to meet the assumptions underlying mens rea. That is, in many, if not most, cases involving a competent defendant with mental retardation, the prosecutor may be able to provide evidence that the defendant acted with the requisite mens rea to commit a particular offense. In the arson example, for instance, to show that the defendant purposely or recklessly engaged in criminal conduct, the prosecution may only need to demonstrate that he started the fire by lighting matches in his neighbor's garage and setting the matches down on or near a stack of old comic books. ${ }^{78}$ But while a presumption of culpability may be valid for defendants of average intelligence, a deeper examination of the capacities and tendencies of people with mental retardation demonstrates the gulf between this assumption and reality for defendants with mental retardation.

Two forces work to undermine the overall culpability of defendants with mental retardation: cognitive capacity and psychosocial capacity. ${ }^{79}$ Deficits in brain function may partially explain why a person with mental retardation cannot form mens rea for a particular offense and, accordingly, should not be criminally liable. ${ }^{80}$ Moreover,

77 Low, supra note 72 , at 548 .

78 Elements for the offense of arson, including the element of intent, vary across jurisdictions. See Model Penal Code $\$ 220.1 \mathrm{cmts}$. 4, 8, \& 9 (1980); id. at nn.57-63, 118-35.

79 Cognitive abilities include attributes such as information processing, comprehension, logic, and abstract reasoning. Non-cognitive deficits might include behavioral components, like impulse control, and social skills, such as social reasoning, judgment, and vulnerability to manipulation or pressure of others. Lois A. Weithorn, Conceptual Hurdles to the Application of Atkins v. Virginia, 59 HASTINGS L. J. 1203,1208 (2008).

${ }^{80}$ See Dora W. Klein, Rehabilitating Mental Disorder Evidence after Clark v. Arizona: Of Burdens, Presumptions, and the Right to Raise Reasonable Doubt, 60 CASE W. RES. L. REV. 645, 649 (2010) ("[D] efendants may offer mental disorder evidence for either or both of two purposes: to prove insanity and to raise reasonable doubt about mens rea."). 
cognitive capacity to form mens rea alone should not necessarily imply a truly culpable intent. Steinberg and Cauffman assert that immature psychosocial and behavioral development should obviate culpability among juveniles, and the same analogy could apply to adults with mental retardation. ${ }^{81}$ Significantly, then, even where there may be evidence that an individual has the requisite mens rea - for example, a person took something that did not belong to him - he still may not have the understanding or culpability that mens rea ostensibly signifies. ${ }^{82}$

One significant difference in making a claim about lack of culpability among juveniles, as opposed to adults with mental retardation, is the type of evidence available to support the argument. Advances in neuroimaging technology enable juvenile advocates to rely not only on psychosocial research regarding the behavioral and cognitive immaturity of young people, but also on brainscanning. ${ }^{83}$ Brainscanning can reveal detailed images, activity, and development of the juvenile brain. ${ }^{84}$ In exempting juveniles from life sentences without parole for non-homicide offenses, recent Supreme Court jurisprudence has relied in part on such neuroimaging advances in finding juveniles categorically less culpable than their adult counterparts. ${ }^{85}$

${ }^{81}$ See Cauffman $\&$ Steinberg, supra note 66 , at $758 ; c f$. Ellis \& Luckasson, supra note 4 (describing historical analogy between children and adults with mental retardation as both were presumed incapable of forming criminal intent).

82 ALEXANDER \& FERZAN, supra note 56 , at 742 ; see also Hermann et al., supra note 14 , at 802 (arguing that program allowing defendants with mental retardation to introduce evidence only to negate mens rea is insufficient to address broader culpability issues); cf. infra note 177 and accompanying text (citing authority for argument that person may demonstrate legal mens rea without actually bearing real culpability).

83 See, e.g., Brief for American Psychological Association et al. as Amici Curiae Supporting Respondent at 9-12, Roper v. Simmons, 543 U.S. 551 (2005) (No. 03-633) (citing neuropsychological research to demonstrate that "the adolescent brain has not reached adult maturity").

${ }^{84}$ There are a range of neuroimaging technologies, but most relate to advances in magnetic resonance imaging ("MRI"), which provides incredibly detailed pictures of brain anatomy. Most pertinently, functional MRIs ("fMRIs") actually track images of the brain while it is engaged in a particular function, providing data about underlying "neuronal or metabolic activity." Teneille Brown \& Emily Murphy, Through a Scanner Darkly: Functional Neuroimaging as Evidence of a Criminal Defendant's Past Mental States, 62 Stan. L. ReV. 1119, 1127 (2010).

${ }^{85}$ See Graham v. Florida, 130 S. Ct. 2011, 2026 (2010) (citing past psychosocial research about "the nature of juveniles" and noting that "brain science continue[s] to show fundamental differences between juvenile and adult minds. For example, parts of the brain involved in behavior control continue to mature through late 
For numerous reasons, neuroimaging research is not nearly as clear for adult defendants with mental retardation. First and foremost, while longitudinal studies demonstrate relatively consistent brain structure and maturation among children and adolescents, ${ }^{86}$ no such consistency exists among people with mental retardation. Although people in this cohort may share a diagnosis with relatively clear cognitive and adaptive features, the etiology giving rise to their intellectual disability is very diverse ${ }^{87}$ Brainscanning studies on people with mental retardation are generally rarer in part because of this hetcrogeneity ${ }^{88}$ Instead, researchers conduct studies in a limited way on those diagnosed with a common genetic etiology, such as Down syndrome $e^{89}$ or Fragile $\mathrm{X}$ syndrome. ${ }^{90}$ This leaves the vast majority of people with mild mental retardation out of the brain-imaging research world, limiting the applicability of any common neurological finding about this subpopulation for criminal justice policy purposes.

adolescence").

86 See Jay N. Giedd et al., Brain Development During Childhood and Adolescence: A Longitudinal MRI Study, 2 NATURE NEUROSCIENCE 861, 861 (1999).

87 One study suggests there are over 750 known genetic causes of mental retardation, accounting for approximately one-third of mental retardation cases. Elisabeth M. Dykens et al., Genetics and Mental. Retardation Syndromes: A New LOOK AT BEHAVIOR AND INTERVENTIONS 3, 5 (2000). Researchers have identified the cause of mental retardation in just $25-40 \%$ of those with mild mental retardation, the group most likely to be found competent in the criminal justice system. 2002 AAMR MANUAL, supra note 3, at 32.

88 Doron Gothelf et al., The Contribution of Novel Brain Imaging Techniques to Understanding the Neurobiology of Mental Retardation and Developmental Disabilities, 11 Mental Retardation \& DeVElopmental Disabilities Res. ReV. 331, 331-32 (2005); see also Manuel Martín-Loeches et al., Electrophysiology and Intelligence: The Electrophysiology of Intellectual Functions in Intellectual Disability, $45 \mathrm{~J}$. INTELL. DisABILITY RES. 63, 63-64 (2001).

${ }^{89}$ Down syndrome is the most common genetic cause of mental retardation, though it affects only 1 in 730 births. Wayne Silverman, Down Syndrome: Cognitive Phenotype, 13 Mental Retardation \& Developmental Disabilities Res. Rev. 228, 228 (2007).

${ }_{90}$ Fragile $\mathrm{X}$ syndrome occurs when an individual has a mutation on a particular, especially "fragile" (i.e., subject to breakage), gene on the X chromosome, such as the FMRl gene. Patricia Ainsworth \& Pamela C. Baker, Understanding Mental RETARDATION 23 (2004). It is the second most common genetic cause of mental retardation, though it affects only one in 2,000 to 4,000 live births. Allan Reiss et al., Brain Imaging in Neurogenetic Conditions: Realizing the Potential of Behavioral Neurogenetics Research, 6 Mental Retardation \& DeVElopmental Disabilities Res. REv. 186, 186 (2000) [hereinafter Brain Imaging]; see Fumiko Hoeft et al., FrontoStriatal Dysfunction and Potential Compensatory Mechanisms in Male Adolescents with Fragile $X$ Syndrome, 28 HUM. BRAIN MAPPING 543, 543 (2007) (using fMRI, only on subjects with Fragile $X$ to reveal evidence of aberrant neural activity in performance of executive function tasks). 
Even among testable genetic subgroups, however, the results of brainscanning studies are very limited. ${ }^{91}$ Studies may also be constrained because research subjects with mental retardation struggle to actually comply with requisite protocols. ${ }^{92}$ When tests are done, they may produce limited findings, as even common etiology does not guarantee consistent results - there may be significant variation in how a genetic mutation affects different individuals. ${ }^{93}$ Finally, it is often difficult for researchers to draw direct connections between some brain abnormality and particular traits, especially those traits as complex as intelligence. ${ }^{94}$

Despite these limitations, some developments in neuroimaging studies confirm the social science studies regarding people with mental retardation. In this Part, I challenge the validity of the mens rea presumptions - and, accordingly, the implication of culpability - for individuals with mental retardation in light of psychosocial and neuroscientific research.

\section{A. Consciousness}

As noted above, two different aspects of consciousness underlie the association between mens rea and culpability: awareness of a legal or moral norm and awareness of one's own conduct and its likely consequences. ${ }^{95}$ These two aspects of consciousness each entail different cognitive and psychosocial skills, all of which may be impaired in people with mental retardation. ${ }^{96}$

91 See Hoeft, supra note 90 , at 544 (noting limited functional neuroimaging studies among certain Fragile X populations); Katie R. Williams et al., Emotion Recognition by Children With Down Syndrome: Investigation of Specific Impairments and Error Patterns, 110 AM. J. ON MENTAL RetARDATION, 378, 390 (2005) (noting lack of neurological studies on Down syndrome subjects to further elucidate psychological testing results).

${ }_{92}$ See, e.g., Curry, supra note 6 , at 474 (noting that subjects of fMRI screenings with mental retardation may require sedation); Gothelf, supra note 88 , at 338 (suggesting that subjects with developmental disabilities may be unable to complete typical cognitive tasks and may struggle to stay still in scanner for fMRI analysis).

${ }_{93}$ For instance, Fragile $\mathrm{X}$ affects males and females differently. Females tend to have a broader range of symptoms, but are generally less affected than males. S.H. Mostofsky et al., Decreased Cerebellar Posterior Vermis Size in Fragile X Syndrome: Correlation with Neurocognitive Performance, 50 NEUROLOGY 121, 121 (1998); see also Hoeft, supra note 90 , at 544 ("To date, the only functional neuroimaging studies in [Fragile $\mathrm{X}$ ] are with females, most likely because of the challenge of imaging male individuals with serious cognitive and behavioral problems.").

${ }^{94}$ See Martín-Loeches, supra note 88, at 72.

95 See supra Part I.A.

96 See Shawn D. Anderson \& Jay Hewitt, The Effect of Competency Restoration 
Cognitively, people diagnosed with different severity levels of mental retardation may not always have the capacity to glean what norms exist in a given community. First, one of the key features of mental retardation is a limited intelligence. ${ }^{97}$ Even those with "mild" mental retardation who receive all necessary supports and training are unlikely to achieve academic skills beyond the sixth-grade level. ${ }^{98}$ Those with "moderate" retardation probably will not progress beyond second-grade work. ${ }^{99}$ These cognitive deficits can limit even basic skills or information acquisition. ${ }^{100}$ For instance, individuals with mental retardation struggle with literacy, preventing them from reading about or otherwise learning what rules they are expected to comply with. ${ }^{101}$ Some neuroscience evidence supports these findings. In people with Down syndrome, for example, verbal processing deficits have been linked to a smaller planum temporal and other abnormal brain development issues. ${ }^{102}$

Social transmission of moral and legal norms is also unlikely to occur in people with mental retardation. They rarely socialize with peers of average intelligence, who may have greater access to and may be likely to disseminate media and other messages about permissible and impermissible conduct (however skewed it may be). ${ }^{103}$ As some

Training on Defendants with Mental Retardation Found Not Competent to Proceed, 26 L. \& HUM. BEHAV. 343, 344 (2002) (noting that low IQ and poor adaptive functioning are chronic disabilities for people with mental retardation).

97 See supra note 3 and accompanying text.

98 DSM-IV-TR, supra note 3, at 43.

99 Id.

100 See Atkins v. Virginia, 536 U.S. 304, 320 (2002) (including "diminished ability to understand and process information" and "to engage in logical reasoning" among cognitive and behavioral impairments of people with mental retardation).

101 See, e.g., Cloud et al., supra note 21, at 514 (explaining that an individual with mental retardation who has been arrested may refuse phone call not because he is uninterested in speaking with anyone, but rather because he may not remember any phone numbers, may be unable to read a phone book, or may not even know how to operate the phone)

102 See Deborah J. Fidler et al., The Down Syndrome Behavioural Phenotype: Taking a Developmental Approach, 12 DOWN SYNDROME RES. \& PRACTICE 37, 41 (2008), available at http://www.down-syndrome.org/reviews/2069/reviews-2069.pdf (providing examples of behavioral profiles "rooted in the genetic and biological insult" that is the genetic basis for Down syndrome).

103 See AINSWORTH \& BAKER, supra note 90, at 114-15 (discussing potential for limited social options for people with mental retardation and their resulting dependence on family members or paid caregivers for recreation and socialization); Robert Perske, Unequal Justice?: What Can Happen When Persons with RETARDATION OR Other DeVElopmental Disabilities ENCOUNTER the CRIMINAL Justice SYSTEM 18 (1991) (indicating that adults with retardation often "fail to relate well with 
experts in mental retardation have put it bluntly: "Developmentally disabled people typically lack social skills and have not had the same opportunities or peer group contact so critical in the development of appropriate social behavior that normal individuals have had." 104

Even if taught the rules, a person with mental retardation may not be able to understand ${ }^{105}$ or remember ${ }^{106}$ such information (much less its social, moral, and legal value). As Miles Santamour, a former consultant to the President's Committee on Mental Retardation, explained, "[t]he majority of mentally retarded persons don't understand why it's wrong to steal, but they will say it's wrong to steal." 107 Moreover, people with mental retardation may have difficulty abstracting ${ }^{108}$ or applying lessons learned on one occasion to a subsequent context, making it difficult to confirm whether they have actually learned and understood a rule. ${ }^{109}$

Evidence indicates that these deficits occur in criminal justice contexts as well. For example, the inability to understand written and unwritten prison rules manifests itself in a disproportionately high rate of infractions among prison inmates with mental retardation. ${ }^{110}$ Similarly, studies show that people with mental retardation do not fully understand the Miranda rights provisions. ${ }^{111}$ Individuals with mental retardation, and even those who tested just above the IQ level defining mental retardation, cannot understand the Miranda warnings,

those their age" and are likely to relate best to children or elderly adults).

104 Sarah F. HaAvik \& Karl A. Menninger, II, Sexuality, Law, and the DeVelopmentally Disabled Person 152 (1981).

105 See, e.g., John J. McGee \& Frank J. Menolascino, The Evaluation of Defendants with Mental Retardation in the Criminal Justice System, in THE CRIMINAL JUSTICE SYSTEM and Mental Retardation: Defendants and Victims 55, 58 (Ronald W. Conley et al. eds., 1992) (citations omitted) ("[P]eople with mental retardation encode information in an extremely limited manner, and .. . Iose[] information at a much faster rate" than their non-retarded peers); see also Ellis \& Luckasson, supra note 4, at 428 (describing limited comprehension of "receptive" communications among people with mental retardation, hampering their ability to understand questions, instructions, or directions).

106 See Ellis \& Luckasson, supra note 4, at 428.

107 Dee Reid, Unknowing Punishment, 15 StUdent LaW. 18, 21 (1986).

108 See Rosalyn Kramer Monat, Sexuality and the Mentally Retarded 33 (1982).

109 See McGee \& Menolascino, supra note 105, at 58 (citations omitted).

110 Garcia \& Steele, supra note 18 , at 835.

111 Cloud et al., supra note 21 , at 501 ("[M]entally retarded people simply do not understand the Miranda warnings."); see also Caroline Everington \& Solomon M. Fulero, Competence to Confess: Measuring Understanding and Suggestibility of Defendants with Mental Retardation, 37 MENTAL RETARDATION 212, 213 (1999) (citing studies indicating "that significant deficits in understanding [Miranda rights] appear to exist for this population"). 
including both the meaning of individual words (even with simplified vocabulary) and the concepts behind them. ${ }^{112}$

The second form of consciousness, an understanding of how one's own actions might impact another, may also demand abilities that most people with mental retardation may not possess. Even though a person's lack of understanding may not approach the total failure to appreciate her own actions that some insanity standards require, ${ }^{113}$ she may nonetheless fail to fully appreciate her own capacity, conduct, or impact. ${ }^{114}$ For example, people with mental retardation may not recognize the relationship between cause and effect. This may be because they lack substantive education (they never learned or figured out how fire travels), or because the idea of a series of interrelated events in a chain is too complex and abstract for a person of limited intelligence to comprehend. ${ }^{115}$

Not surprisingly, social situations reveal these deficits in understanding one's relationship to others. That is, people with mental retardation face difficulty anticipating or, subsequently, understanding how their own actions could impact or harm other people. ${ }^{116}$ While this concern is particularly relevant in a person's choice whether to adhere to a particular norm or rule, as discussed below, it may also have implications for the individual's understanding of whether rules exist, as well as the scope and application of those rules to the individual. ${ }^{117}$

112 Cloud et al., supra note 21 , at 538-39.

113 See, e.g., MODEL PENAL CODE \& 4.01(1) (1985) (defining insanity as circumstances where a defendant "lacks substantial capacity" to "appreciate the criminality [wrongfulness] of his conduct or to conform his conduct to the requirements of the law").

114 Reid, supra note 107 , at 21 ("[M]ental retardation can interfere greatly with the ability to ... even understand the nature or consequences of one's actions.").

115 See John Langone, Mild Mental Retardation, in MENTAL ReTardation AND DeVELOPMENTAL DisABILITIES 113, 121 (2d ed. 1996) ("The major characteristic shared by all ... learners with mild to moderate disabilities is that they fall significantly behind their general education peers in tasks that require learning using academic skills .... [l]ndividuals with mental retardation are slow to learn new skills, do not grasp concepts well at symbolic or abstract levels, are inefficient learners, and do not readily transfer learned skills to new settings or when different materials are required.").

116 See McGee \& Menolascino, supra note 105, at 59 (explaining that people with mental retardation have difficulty recognizing social cues, understanding the reactions of others, or comprehending their own role in relation to another); see also Langone, supra note 115, at 124 (suggesting that individuals with mental retardation tend to lack self-direction and accordingly fail "to see the cause-and-effect relationship between [their] behavior and subsequent events").

117 See Philip L. Fetzer, Execution of the Mentally Retarded: A Punishment Without 
Overall, the presumption of awareness that partially undergirds the connection between mens rea and culpability simply does not hold true for people with mental retardation. Because of mental capacity, training, and socialization, defendants in this population are unlikely to intuit, learn, or understand what society expects of them. Moreover, they may be unaware of the full nature of their behavior and its consequences.

\section{B. Choice}

Even if a person with mental retardation knows about and generally understands a rule, it is unlikely that she could make a meaningful choice about whether or not to engage in particular conduct or to violate a particular norm. Because of difficulties in the overlapping areas of decision-making, moral reasoning, and independent thinking, people with mental retardation may not be able to make a reasoned choice.

In general, people with mental retardation struggle with the analytical skills necessary for thoughtful decision-making. For instance, they often lack problem-solving skills, particularly where the problem requires some level of "formal thinking" or abstract analysis. ${ }^{118}$ Even people with mild mental retardation are typically limited to concrete thinking or superficial categorization. ${ }^{119}$ Thus, people with mental retardation likely lack the ability to perform the sort of cost-benefit analysis that people with average intelligence might engage in before making a decision. ${ }^{120}$ They also cannot engage in "if-then" propositions or other mental predictions, strategic thinking, or foresight. ${ }^{121}$ Instead of employing novel or problem-

Justification, 40 S.C. L. REV. 419, 439 (1988).

118 Am. Ass'N ON Mental Deficiency, Classification in MENTal Retardation 36-37 (Herbert J. Grossman ed., 8th ed. 1983) ("Mildly retarded people ... do not appear to enter into formal thinking operativity and may have difficulty with concrete operativity," and those with moderate mental retardation appear to end cognitive development "at the preoperational-intuitive stages."); see also Jones, supra note 4 , at 727 (referring to "cognitive deficits and limited problem-solving abilities" of people with intellectual disabilities).

119 Appelbaum \& Appelbaum, supra note 11, at 488 (providing example of mildly mentally retarded individuals who can sort items based on appearance or functionality but cannot engage in more abstract reasoning; adults classified as moderately mentally retarded would only be able to sort based on appearance).

120 See Atkins v. Virginia, 536 U.S. 304, 320 (2002) (finding deterrence rationales inapplicable to defendants with mental retardation).

121 Appelbaum \& Appelbaum, supra note 11, at 488 (citing Herman H. Spitz, Intellectual Extremes, Mental Age, $\mathcal{G}$ the Nature of Human Intelligence, 28 MERRILL- 
solving techniques, individuals with mental retardation rely on familiar behaviors or responses, even if those mechanisms have been unsuccessful in the past. ${ }^{122}$

In addition to lacking analytical skills, this population has specific disabilities when it comes to making moral decisions. A person with mental retardation may lack the tools required to make the decision that certain conduct is wrongful - a necessary step before he can even reject the behavior in favor of compliance with a social or moral norm. ${ }^{123}$ People with mental retardation may have a less mature or complete moral development than others due to limitations in a range of cognitive and psychosocial factors, including intelligence, limited opportunity for interaction with others, exclusion from an enriching environment, chronological age, and mental age. ${ }^{124}$ These circumstances have profound effects on an individual's ability to develop and sustain a moral framework in which to evaluate the effect of his own conduct, even if he is aware of community norms. ${ }^{125}$

This capacity to choose also requires a sense of agency and selfdetermination that many people with mental retardation lack, often because of their longstanding relationship with and dependence upon caregivers. ${ }^{126}$ Indeed, parents and other caretakers of people with mental retardation may be so overprotective that their children develop a so-called "functional retardation" even beyond their intrinsic intellectual disability. Consequently, they fail to develop initiative, social skills, and other mature behaviors because of a learned fear of and inexperience with independence. ${ }^{127}$

This lack of agency is one of the scenarios that experts most often point to in explaining the criminal involvement of people with mental

PALMER Q. 167, 167-78 (1982)).

122 R.S. Rueda \& S.H. Zucker, Persuasive Communication Among Moderately Retarded and Nonretarded Children, 19 Educ. \& TRaining MENTAlly Retarded 125, 125-31 (1984).

123 McGee \& Menolascino, supra note 105, at 59-60.

124 Ellis \& Luckasson, supra note 4 , at $429 \mathrm{n} .78$ (citing factors relating to moral development).

125 See Courselle et al., supra note 22, at 23 (2001) (citing McGee \& Menolascino, supra note 105, at 60) ("Full moral development takes into account the consequences of an action not just for actor, but more abstract concepts such as how others will be affected by the action.").

126 Elizabeth J. Reed, Note, Criminal Law and the Capacity of Mentally Retarded Persons to Consent to Sexual Activity, 83 VA. L. Rev. 799, 810-11 (1997) (noting that people with mental retardation often lack assertiveness and decision-making abilities because of dependence on caregivers).

127 AINSWORTH \& BAKER, supra note 90, at 124. 
retardation. ${ }^{128}$ Indeed, people with mental retardation are frequently trained to be - and rewarded for being - compliant with the wishes and demands of others, including those with malicious or criminal intent. ${ }^{129}$ Relatedly, because of their low social status, people with mental retardation suffer diminished self-esteem ${ }^{130}$ and are eager to conceal their disability and "pass" as a person of average intelligence. ${ }^{131}$

Accordingly, even adults with mental retardation are highly manipulable. ${ }^{132}$ This is consistent with some of the neurological findings regarding individuals with Down syndrome. ${ }^{133}$ People with Down syndrome tend to experience high levels of atrophy in the amygdala part of their brains, particularly as they age. ${ }^{134}$ Research

128 See, e.g., Joan Petersilia, Cal. Policy Research Ctr., Doing Justice? Criminal OfFenders WITH Developmental Disabilities 12 (2000) (explaining how interest in pleasing authority often leads to false confessions of innocent suspects with mental retardation); Hubert R. Wood \& David L. White, A Model for Habilitation and Prevention for Offenders with Mental Retardation, in THE CRIMINAL JUSTICE SYSTEM AND Mental RetaRdation: DeFEndANTS AND Victims, supra note 105, at 157, 162 (pointing to "influence of ... peers" as factor leading to criminal justice system involvement and noting defendants with mental retardation "are easily manipulated and often taken advantage of by other more intelligent and/or more experienced individual. [They] are more often followers and not leaders in breaking the law"); see also Everington \& Fulero, supra note 111 , at 212-13 (pointing to strong desire to please others, acquiescence, "outerdirectedness" (responsiveness to social cues from others instead of personal problem solving), and vulnerability to pressure from others as partial basis for frequency of confessions from defendants with mental retardation); Stephen Greenspan, Functional Concepts in Mental Retardation: Finding the Natural Essence of an Artificial Category, 14 EXCEPTIONALITY 205, 215 (2006) ("II]f there is a universal quality that all people with mild MR possess and that defines its natural essence, it is a vulnerability to social exploitation owing to an inability to understand other people, especially when their motives are malevolent but disguised as benevolent.").

129 See Dick Sobsey \& Tanis Doe, Patterns of Sexual Abuse and Assault, 9 SeXuality $\&$ DisABILITY 243, 252 (1991)

130 See MONAT, supra note 108 , at 8 ("The mildly mentally retarded are often viewed as having very poor self imagery and self worth."); Jones, supra note 4, at 729 ; Sobsey \& Doe, supra note 129, at 253 (discussing damage of stigmatization to individuals' self-image).

131 Robert Edgerton, THE Cloak OF COMPeTEnCE: Stigma in the Lives OF THE MENTALLY RETARDED 192, 217-18 (1967) (stating that people with mental retardation were "dogged" in efforts to pass as "normal," and struggled to "maintain [their] selfesteem" by hiding their "incompetence").

132 Greenspan, supra note 128 , at 215.

133 J.D. Pinter et al., Amygdala and Hippocampal Volumes in Children with Down Syndrome: A High Resolution MRI Study, 56 NeUROLOGY 972, 972 (2001); Silverman, supra note 89 , at 228.

134 Pinter et al., supra note 133, at 973. 
suggests that a dysfunctional amygdala can cause a person to be overly trusting. 135

Social science research also suggests that in both criminal and noncriminal circumstances, the need for social acceptance makes people with mental retardation prone to suggestibility and acquiescence, regardless of whether they might actually disagree with their interlocutor. ${ }^{136}$ Thus, while individuals may appear to make an affirmative, knowing act, their conduct may not be considered the product of their own independent will. To fit in or please someone, of higher status, for instance, they might agree to serve as a lookout, do a drug buy, or participate in an assault. ${ }^{137}$

Indeed, although much of criminal law regards these individuals as perpetrators, in many circumstances it may be more accurate to describe them as victims. ${ }^{138}$ In limited ways, the law acknowledges this alternative characterization. That is, many states make it a form of statutory rape for individuals to have sex with people whom they know or should know have mental retardation. ${ }^{139}$ The Supreme Court has even drawn an explicit connection between this tendency toward vulnerability and culpability, finding that susceptibility to manipulation is a key reason that people with mental retardation should not be subject to the death penalty. ${ }^{140}$ As discussed below, the lack of independence may further indicate non-culpability when it comes to executing a particular decision or actually engaging in a

135 See Ralph Adolphs et al., A Mechanism for Impaired Fear Recognition after Amygdala Damage, 433 Nature 68, 68-69 (2005); Michael Davis \& Changjun Shi, The Amygdala, 10 CURRENT BIOLOGY R131 (2000).

136 See PeterSILIA, supra note 128, at 14; Everington \& Fulero, supra note 111, at 213 (citing Carol K. Sigelman et al., When in Doubt, Say Yes: Acquiescence in Interviews with Mentally Retarded Persons, 19 Mental Retardation 53, 53-58 (1981)) (providing empirical data to suggest subjects with mental retardation will agree to even a preposterous statement); Reichard et al., supra note 11, at 227 ("[R]etarded people may be easily led and be open to the suggestions of others; they may be . . unable to answer questions; ... and they may say what they think one wants them to say, including confessing to anything, in order to curry favor.")

137 See, e.g., Ballou v. Booker, 777 F.2d 910, 911 (4th Cir. 1985) (suggesting that defendant's confession concerning sexual assault occurred because victim's parents urged him to make such a statement to police).

138 See Sobsey \& Doe, supra note 129, at 253; see also MONAT, supra note 108, at 8 .

139 Deborah W. Denno, Sexuality, Rape, and Mental Retardation, 1997 U. ILL. L. REV $315,397-403,397$ tbl.B (charting laws which include complainant's mental incapacity as basis for statutory rape).

140 See Atkins v. Virginia, 536 U.S. 304, 318 (2002) (recognizing that mental retardation can make person follow rather than lead and, thus, be, less culpable than other offenders). 
course of conduct. However, this vulnerability first comes into play in the choice to violate an established norm.

\section{Control}

The final prong underlying the connection between culpability and mens rea is the assumption that an individual acts intentionally and thoughtfully on his choice to comply with or violate social norms. People with mental retardation may suffer from poor impulse control and vulnerability to undue pressure to act from others. Both of these features of mental retardation make it difficult to claim that this population is truly responsible for its own conduct.

In the juvenile context, both the social science and neuroscience literature have documented the tendency among young people towards limited impulse control. ${ }^{141}$ Based in part on these findings, the Supreme Court has deemed young people less culpable as a class and constitutionally shielded them from the most severe sentences, such as the death penalty ${ }^{142}$ and life without parole for non-homicide offenses. ${ }^{143}$

Limited impulse control is also a key feature of mental retardation. ${ }^{144}$ Accordingly, the Supreme Court has also acknowledged that a lack of impulse control among people with mental retardation partially accounts for their reduced culpability. ${ }^{145}$ For those whose mental retardation derives from a genetic condition known as Fragile $\mathrm{X}$ syndrome, there may be neurological evidence related to this feature. ${ }^{146}$ In both males and females with Fragile X, structural MRI

141 E.g., Mary Beckman, Crime, Culpability, and the Adolescent Brain, 305 SCI. 596, 597-98 (2004); Laurence Steinberg \& Elizabeth Scott, Less Guilty by Reason of Adolescence, 58 AM. PsycHOL. 1009, 1013-14 (2003); Kim Taylor-Thompson, States of Mind/States of Development, 14 STAN. L. \& POL'Y REV. 143, 153 (2003) (pointing to research on impulsivity among adolescents as potential cause of risk-seeking behavior).

142 See Roper v. Simmons, 543 U.S. 551, 568-69 (2005) (citation omitted) (abolishing death penalty for juveniles in part because of their "impetuous and illconsidered actions and decisions").

143 See Graham v. Florida, 130 S. Ct. 2011, 2026 (2010) (striking down sentences of life imprisonment without parole for juveniles convicted of non-homicide offenses, based in part on evidence that they have impaired impulse control).

144 See, e.g., Ellis \& Luckasson, supra note 4, at 429 (citing social science research suggesting impulsivity and poor impulse control as common traits of people with mental retardation).

145 Atkins v. Virginia, 536 U.S. 304, 318 (2002) ("[T]here is abundant evidence that [persons with mental retardation] often act on impulse rather than pursuant to a premeditated plan, and that in group settings they are followers rather than leaders.").

146 See sources cited supra note 93 for more on Fragile X syndrome. 
studies show an enlarged caudate nucleus, located in the basal ganglia part of the brain. ${ }^{147}$ Studies of lesions in the basal ganglia have shown "disturbances in attention control, response inhibition, cognitive flexibility, and goal-oriented behavior," phenotypes which frequently also apply to people with Fragile X. ${ }^{148}$ Researchers have further suggested that dysfunction in networks including the caudate could contribute to deficits in executive function and impulsivity. ${ }^{149}$ And still other neuropsychiatric studies have suggested that amygdala dysfunction would contribute to diminished fear conditioning, which in turn could increase impulsivity and risk taking. ${ }^{150}$ As noted above, while people diagnosed with Down syndrome do not have amygdala dysfunction per se, they may have atrophied amygdalas, particularly as they age. ${ }^{151}$

Even where a person with mental retardation has the neural ability to demonstrate impulse control, the individual may still lack real control over her actions because of a susceptibility to pressure from others. Given the research on this dynamic outlined with regard to "choice," above, as well as the law's acknowledgment of its relevance to culpability, we cannot assume that a person with mental retardation truly controls - and therefore should be responsible for - her own conduct.

Thus, the scientific (and social science) research makes clear that people with mental retardation lack many of the capacities that endow a finding of mens rea with an assumption of culpability. The question,

147 Allan Reiss et al., Neurodevelopmental Effects of the FMR-1 Full Mutation in Humans, 1 NATURE MED. 159, 161 (1995).

148 David Hessl et al., The Neuroanatomy and Neuroendocrinology of Fragile $X$ Syndrome, 10 Mental Retardation \& Developmental Disabilities Res. Revs. 17, 18 (2004) (citing M.T. Abrams \& A.L. Reiss, The Neurobiology of Fragile X Syndrome, 1 Mental Retardation \& Developmental Disabilities Res. Revs. 269 (1995)); Michele M. Mazzocco et al., The Neurocognitive Phenotype of Female Carriers of Fragile X: Additional Evidence for Specificity, 14 J. Dev. Behav. Pediatrics 328, 333-34 (1993).

149 See Hoeft, supra note 90, at 552 ("converging results" in Fragile X research including morphometric imaging of increased caudate volumes indicate that "abnormal development and function of the human [prefrontal cortex], striatum, and fronto-striatal network . . . could contribute to many of the cognitive and behavioral manifestations of the syndrome including deficits in executive function, impulsivity, hyperactivity, and some autistic behaviors."); V. Menon et al., Frontostriatal deficits in fragile $X$ syndrome: Relation to FMR1 gene expression, 101 PROCS. NAT'L ACAD. SCIS. U.S. 3615,3619 (2004) ("Disturbances of [] frontal subcortical circuits are known to produce problems in executive function, motor programming, regulation of affect, social behavior, impulse control, and flexibility in response to environmental cues.").

150 Justin S. Feinstein, et al., The Human Amygdala and the Induction and Experience of Fear, 21 CURRENT BIOLOGY 34, 36-37 (2011).

151 See Pinter et al., supra note 133, at 973. 
then, is to what extent the law acknowledges this important difference in its doctrines of criminal responsibility. As I argue in the next section, there are a number of ways in which criminal law purports to account for differences in cognitive capacity (including the competency, insanity, and diminished capacity doctrines), but none of these is sufficient to remedy the injustice of presuming mens rea signifies actual culpability among defendants with mental retardation.

\section{THE STATUS QUO: HOW THE SYSTEM FAILS DEFENDANTS WITH MENTAL RETARDATION}

As I have suggested, a finding of mens rea is typically thought to demonstrate that a defendant has crossed at least a threshold level of blameworthiness. ${ }^{152} \mathrm{~A}$ patchwork of other legal areas - namely, insanity, competency, and diminished capacity - arguably supplement the mens rea inquiry into culpability insofar as they provide some acknowledgment of the relationship between mental disability and criminal responsibility. But they do so in a way that tends to champion social control, public safety, and efficiency over individualization and fairness. As set forth below, these doctrines are insufficient responses to the lack of culpability among defendants with mental retardation. This gap in the law results in perversions of justice not only for individual defendants, but also for criminal law itself, as litigants and courts seek to employ both sentencing and novel defense strategies in lieu of substantive legal doctrines. Because the current legal landscape fails to properly account for the difference in culpability among defendants with mental retardation, in the final Part of this paper, I propose a new legal avenue for addressing cases involving this class of defendants.

\section{A. At the Margins: Substantive Criminal Law Doctrines that Address Mental Retardation}

\section{Competency}

The competency and insanity doctrines are the law's primary answer to defendants who claim that their mental disability makes them nonresponsible for their otherwise criminal conduct. Accordingly,

152 Smith, supra note 31, at 127 (indicating that mens rea doctrine does "guarantee a modicum of moral blameworthiness as a precondition to punishment"). Smith's argument, however, is that such a baseline signifier of culpability fails to fulfill the traditional role of mens rea in that it allows for sentencing that is disproportionate to relative blameworthiness. Id. at 127-28. 
these two doctrines skim the least culpable individuals with mental retardation - those with "gross" and "verifiable" disabilities - out of the pool of defendants at some point in the criminal process. ${ }^{153}$

The competency doctrine does not specifically speak to culpability, but it mandates a connection between criminal responsibility and cognitive understanding. Under the Due Process Clause, defendants who cannot rationally and factually understand the proceedings against them and/or cannot consult with their attorney "with a reasonable degree of rational understanding" are legally incompetent and, therefore, ineligible for prosecution or sentencing. ${ }^{154}$ Those whom a court determines (after psychiatric and/or psychological evaluation) to be unlikely to regain competency are typically referred to the jurisdiction of the public mental health system. ${ }^{155}$ In such cases, the facts of the alleged criminal offense may then be used to demonstrate that they are too dangerous to remain free in the community ${ }^{156}$ After hearings or even a trial, these defendants may face involuntary civil commitment. But, they avoid criminalization and a criminal record unless and until they gain competency (or have it "restored"). ${ }^{157}$ In part because incompetency can be considered a "get out of jail free" card, its exercise is quite constrained. ${ }^{158}$

Ultimately, when it comes to defendants with less severe forms of mental retardation, the law of competency privileges public safety and

153 See United States v. Moore, 486 F.2d 1139, 1180 (D.C. Cir. 1973) (Leventhal, J., concurring) ("The criminal law cannot vary legal norms absent a disability that is both gross and verifiable .... A few may be recognized as so far from normal as to be entirely beyond the reach of criminal justice, but in general, the criminal law is a means of social control that must be potentially capable of reaching the vast bulk of the population."); see also supra note 15 and accompanying text (providing statistics on the rarity of defendants being found insane or incompetent).

${ }^{154}$ Dusky v. United States, 362 U.S. 402, 402 (1960) (stating that findings of competency require district judge to analyze defendant's ability to consult rationally with his attorney); see also State v. Garfoot, 558 N.W.2d 626, 632 (Wis. 1997) ("[A] defendant may be incompetent based on retardation alone if the condition is so severe as to render him incapable of functioning in critical areas."). The assessment considers the individual's status at the time of the legal proceedings and, therefore, may become an issue any point in the process, up to and including sentencing. See Drope v. Missouri, 420 U.S. 162, 181 (1975).

155 Joshua Dressler, Understanding CRiminal Law 341-42 (5th ed. 2009) [hereinafter UNDERSTANDING].

${ }^{156}$ Id. The proceedings following the finding of incompetency, if any, occur pursuant to a state's civil commitment law and may result in involuntary hospitalization or other compelled treatment, services, or habilitation.

157 Id.

158 See supra note 15 and accompanying text on infrequency of incompetency findings. 
prosecution over individualization and fairness. The competency doctrine not only requires a near complete lack of awareness on the part of the defendant, ${ }^{159}$ but also stands as a perversely ineffective legal response to people with mental retardation. First, it makes little sense to presume that people with mental retardation might be "restored" to competency over a period of weeks or months of treatment; their cognitive condition is unlikely to change dramatically, if at all. ${ }^{160}$ Moreover, because people with such intellectual disabilities typically try to conceal their disability from others, they may evade efforts to detect their incompetency. ${ }^{161}$ The difficulty identifying defendants who actually meet the legal standard for incompetency is further magnified because defense counsel typically lack the time, funding, and specialized training required to effectively interview or even identify clients with mental retardation. ${ }^{162}$ Thus, a combination of policy limitations on the doctrine, resistance among individuals to be considered incompetent, and challenges in identifying mental retardation results in an under-referral of these defendants for competency evaluation. ${ }^{163}$

159 See Godinez v. Moran, 509 U.S. 389, 402 (1993) (acknowledging that competency doctrine has "modest aim" and minimal requirements); see also Bonnie, supra note 15, at 422-23, 429 (noting that "the threshold of competence for defendants with mental retardation is set relatively low in practice"); Ronald Schouten, Commentary: Training for Competence - Form or Substance?, 31 J. AM. ACAD. PsychIATRY L. 202, 203 (2003).

160 Defendants with mental retardation can receive training to become competent; however, their cognitive understanding is not likely to increase significantly. See Ellis $\&$ Luckasson, supra note 4, at 424 ("[L] egal rules which focus upon the prospect of 'curing' mentally ill people may not address the condition of retarded people in an appropriate or useful fashion."); see also Shawn D. Anderson \& Jay Hewitt, The Effect of Competency Restoration Training on Defendants with Mental Retardation Found Not Competent to Proceed, 26 LAw \& HUM. BEHAV. 343, 344, 349-50 (2002) (finding that competency restoration is uncommon among defendants with mental retardation, and that successful competency restoration typically requires relatively high IQ and significant investment of time and tailored treatment). But cf. Dan Hurley, All I Could Think is She's My Baby, She's a Lovely Girl and What Can I Do to Help Her?, N.Y. TIMES MAG., July 31, 2011, at 28, 31 (suggesting that "with vigorous education and support, many people with Down [syndrome] do far better than once thought possible").

161 See Michael L. Perlin, The Jurisprudence of the Insanity Defense 240-41 (1994); Ellis \& Luckasson, supra note 4, at 430.

162 See Ellis \& Luckasson, supra note 4, at $422-423$ (explaining difficulties for defense counsel in identifying and responding to clients with mental retardation).

163 Id. at 420-24 (hypothesizing reasons for this "pattern of under-referral"). 


\section{Insanity}

The circumstances relating to the insanity doctrine are similar in that insanity law provides an extremely rare way out of the criminal justice system for defendants with mental retardation. This excuse defense focuses on the culpability question. ${ }^{164}$ It considers whether a defendant should be held criminally accountable despite having a mental condition ${ }^{165}$ that may impair her understanding of her conduct and/or capacity for self-control during commission of the offense. ${ }^{166}$ While definitions of insanity vary widely across the country, legal formulations often break down into two different prongs: a cognitive prong ("I didn't know what I was doing" and/or "I didn't know it was wrong") $)^{167}$ and a volitional prong ("I could not control my own actions"). However, many jurisdictions do not require proof of both of these prongs. ${ }^{168}$ In most jurisdictions, an insanity acquittal results in automatic commitment to a public mental health facility, up to and including indefinite hospitalization. ${ }^{169}$

Regardless of the exact terms of a particular insanity law, the doctrine is limited and has become even more so in recent decades.

164 Insanity is "the paradigmatic excuse defense." Russell D. Covey, Temporary Insanity: The Strange Life and Times of the Perfect Defense, 91 B.U. L. REV. 1597, 1632 (2011). Excuses provide affirmative defenses based on the lack of blameworthiness of the actor, as opposed to "justification" defenses, which validate the defendant's actions based on policy grounds (such as self-defense). Id.

165 While the term "insanity" or, as it appears in some legal standards, "mental disease or defect," may suggest that the defense applies only to those with mental illnesses, mental retardation, itself or in combination with mental illness, may also serve as the basis of an insanity defense. See, e.g., United States v. Jackson, 553 F.2d 109, 113-14 (D.C. Cir. 1976) ("It is accepted in this jurisdiction that mental retardation is a mental defect that will support an insanity defense.").

166 See Christopher Slobogin, An End to Insanity: Recasting the Role of Mental Disability in Criminal Cases, 86 VA. L. Rev. 1199, 1202 (2000).

167 The Supreme Court has separated the cognitive prong into a cognitive prong and a "moral" one, placing elements such as the ability to distinguish between right and wrong and the ability to understand the wrongfulness of one's actions into the "moral capacity" category. See Clark v. Arizona, 548 U.S. 735, 750 (2006) ("Seventeen States and the Federal Government have adopted a recognizable version of the M'Naghten test with both its cognitive incapacity and moral incapacity components.").

168 The Model Penal Code's definition of insanity, for instance, allows for these prongs to be argued in the alternative, requiring that an individual "lacks substantial capacity either to appreciate the criminality [wrongfulness] of his conduct or to conform his conduct to the requirements of the law" due to a mental disease or defect. Model Penal CODE $\$ 4.01$ (1) (1985) (emphasis added).

169 See A. Thomas Elliott, Procedures for Involuntary Commitment on the Basis of Alleged Mental Illness, 42 U. COLO. L. Rev. 231, 234-35 (1970). 
While public perception may be that the defense is commonplace, ${ }^{170}$ studies suggest that less than one percent of criminal defendants try to use the insanity defense and, of these, only one-quarter use it successfully. ${ }^{171} \mathrm{~A}$ thirty-six state survey found an average of 33.4 insanity acquittals per state, per year, from 1970 to 1995, many of them in misdemeanor prosecutions. ${ }^{172}$

Most commentators identify the tipping point leading to the limitation of the defense as the 1982 trial of John Hinckley, who successfully employed it to obtain an acquittal after his assassination attempt on then-President Ronald Reagan. ${ }^{173}$ In the political upheaval following the verdict, many jurisdictions limited the reach of the insanity doctrine. Congress, for instance, dramatically reduced the doctrine's scope with the Insanity Defense Reform Act of 1984 ("IDRA"). ${ }^{174}$ Some jurisdictions abandoned the defense all together. ${ }^{175}$ Over twenty jurisdictions replaced or added to the insanity defense with the more punitive verdicts "Guilty but Mentally Ill" ("GBMI") or

170 See Daniel J. Nusbaum, Note, The Craziest Reform of Them All: A Critical Analysis of the Constitutional Implications of "Abolishing" the Insanity Defense, 87 CORNELl L. REV. 1509, 1512 n.9 (2002) (citing studies showing public's dramatic overestimation use of insanity defense).

171 Laura Reider, Toward A New Test for the Insanity Defense: Incorporating the Discoveries of Neuroscience into Moral and Legal Theories, 46 UCLA L. Rev. 289, 292 n.6 (1998) (citing study on use of insanity defense in eight states).

172 Carmen Cirincione $\&$ Charles Jacobs, Identifying Insanity Acquittals: Is It Any Easier?, 23 LAW \& HUM. BEHAV. 487, 487 (1999). A National Mental Health Association report found that as many of $86 \%$ of insanity pleas occur in nonviolent felonies and misdemeanors. Nat'L MENTAl HEALTH ASS'N, MYTHS \& REalities: A RePORT OF THE NATIONAL COMMISSION ON THE INSANITY DEFENSE 20-21 (1983).

173 See Richard J. Bonnie et al., A Case Study in the InSANITy Defense: The TrLal OF JOHN W. HINCKLEY, JR. 121-27 (2d ed. 2000) [hereinafter CASE STUdY]; HENRY J. StEAdMAN ET AL., BEFORE AND AFTER HinCKLEY: EVAluATING INSANITY DEFENSE REFORM 35-39 (1993); Russell D. Covey, Criminal Madness: Cultural Iconography and Insanity, 61 Stan. L. REV. 1375, 1427 (2009); Richard E. Redding, The Brain-Disordered Defendant: Neuroscience and Legal in the Twenty-first Century, 56 AM. U. L. REV. 51, 98-99 (2006).

174 Under the IDRA, defendants are entitled to acquittal only if a "severe" mental disease or defect rendered him "unable to appreciate the nature and quality or wrongfulness of his acts." 18 U.S.C.A. $\S 17$ (a) (West 1984). At the same time, Congress changed the Federal Rules of Evidence to prohibit experts from opining as to whether the defendant possessed (or not) the requisite mens rea. FED. R. EVID. 704(b).

175 See, e.g., IDAHO CODE $\$ 18-207$ (West 2012) (eliminating the insanity defense since 1982); KAN. STAT. ANN. \& 21-5209 (West 2011) (allowing evidence of mental disease or defect only for purposes of negating mens rea); MONT. CODE ANN. § 46-14102 (2011) (same); UTAH CODE ANN. § 76-2-305(1) (West 2011) (allowing evidence of mental disease or defect only for purposes of negating mens rea since 1983). 
"Guilty but Mentally Retarded" ("GBMR"). ${ }^{176}$ Unlike an insanity verdict, these new verdicts constitute criminal findings, imposing culpability and criminal sentences, notwithstanding a person's inability to control himself or understand his own actions. ${ }^{177}$

This trend of limiting the insanity doctrine has continued long past Hinckley's case. In 1993, for instance, Arizona halved its insanity rule, eliminating the possibility for defendants to claim they did not understand their actions. ${ }^{178}$ Such legislative changes also reflect the public's mistrust of the defense because insanity acquittals seem to unjustly absolve defendants who apparently engaged in criminal conduct. ${ }^{179}$ Ultimately, a number of factors have conspired to limit the insanity doctrine's influence, including its legislative demise, its relatively extreme diagnostic requirements, and even its lack of popularity with the public.

\section{Diminished Capacity}

Litigants who fail to qualify as either incompetent or insane have been forced to rely on just one other doctrine to address their difference in culpability during the case-in-chief: the diminished

176 STEADMAN ET AL., supra note 173, at 35-39 (summarizing state and federal reform efforts following Hinckley case); see also Bradford $\mathrm{H}$. Charles, Pennsylvania's Definitions of Insanity and Mental Illness: A Distinction with a Difference?, 12 TEMP. POL. $\&$ CIV. RTS. L. REV. 265, 268 (2003).

177 Practically speaking, a person found "guilty but mentally retarded" is usually first sentenced in the criminal system without regard to his disability and only then may or may not receive any special treatment or services related to his mental condition. See DRESSLER, UNDERSTANDING, supra note 155, at 365 ("The effect of a GBMI verdict is that the convicted party receives the sentence that would otherwise be imposed if she were found guilty; after sentencing, however, she may receive psychiatric care in the prison setting or in a mental institution."). Alternatively, a defendant found "guilty but mentally ill" may receive mental health treatment until his mental health has rebounded, at which point he must serve the remainder of his imposed sentence. See, e.g., ALASKA STAT. \& 12.47 .050 (2004) (requiring individuals found GBMI who no longer suffer from mental disease or defect to serve the remainder of their sentence imposed).

178 In 1983, post-Hinckley, Arizona became one of the few states to put the burden of proof on the defendant to prove his sanity by clear and convincing evidence. A decade later, the alternative form of the insanity rule was eliminated: since 1993, a defendant must prove that she "did not know the criminal act was wrong." ARIz. REV. StAT. ANN. \& 13.502(A), (C) (2012).

179 Michael L. Perlin, "His Brain Has Been Mismanaged With Great Shill": How Will Jurors Respond to Neuroimaging Testimony in Insanity Defense Cases?, 42 AKRON L. REV. 885,899 (2009) ("The notion of any defense that allows criminals to claim they were not responsible for acts that they admittedly did is rejected in total by a significant percentage of the population."). 
capacity defense. ${ }^{180}$ Diminished capacity has so many different iterations in jurisdictions across the country that it is somewhat difficult to define succinctly. ${ }^{181}$ Most commonly, however, courts and commentators apply the Model Penal Code's definition: evidence of a mental abnormality offered to show that the defendant was not capable of forming the necessary mental state for a particular crime. ${ }^{182}$ In other words, diminished capacity evidence serves to negate mens rea. ${ }^{183}$

In theory, a doctrinal vehicle that permits evidence of mental retardation to challenge or negate mens rea sounds like a fitting response to the unjustified presumption of culpability inherent in a finding of mens rea. If mens rea is the problem, why wouldn't the diminished capacity doctrine suffice to give these defendants an opportunity to introduce the relevance of their disability? Moreover, diminished capacity provides a platform for such evidence where the disability does not rise to the level of insanity. In reality, however, there are two problems with relying on diminished capacity to cure such ills for defendants with mental retardation: limitations on its application in practice and limitations on its application in theory.

First, like tests for insanity and competence, the diminished capacity defense has been so watered down - particularly over the past halfcentury - that it is a virtually useless defense for most people with mental disabilities. Some states have banned diminished capacity defenses altogether. ${ }^{184}$ Other states only allow the defense in murder

180 While sometimes called a defense (here and elsewhere), it is more aptly considered an issue of evidentiary relevance or sufficiency: an argument that the government has not met its burden to prove the defendant had the requisite mens rea beyond a reasonable doubt. See Hendershott v. People, 653 P.2d 385, 393-94 (Colo. 1982).

181 See DRESSLER, UNDERSTANDING, supra note 155, at 367-76 (suggesting that there are at least four different versions of diminished capacity and stating that "Iblecause of the confusion pervading this area of the law, any generalization about it is just that - a generalization subject to exceptions and inconsistencies").

182 Jennifer Kunk Compton, Expert Witness Testimony and the Diminished Capacity Defense, 20 Am. J. Trial AdVOC. 381, 382 (1996).

183 See MODEL PENAL CODE $\S 4.02$ (1) (1985) ("Evidence that the defendant suffered from a mental disease or defect is admissible whenever it is relevant to prove that the defendant did or did not have a state of mind that is an element of the offense."). Ambiguities in legal opinions and dicta make it unclear how many states actually apply the Model Penal Code standard, but Dressler notes that the figure seems to be between 11 and 15 states. DRESSLER UNDERSTANDING, supra note 155, at 369.

184 Arizona, for instance, prohibits evidence of a defendant's mental disorder for anything but an insanity defense, including evidence to negate mens rea. Clark v. Arizona, 548 U.S. 735, 742 (2006) (finding that Arizona's limitation on use of evidence of mental illness comports with due process); see also CAL. PENAL CODE 
prosecutions. ${ }^{185}$ Very few states permit the defense outside of specific intent crimes. ${ }^{186}$ In Wyoming or Connecticut, for example, if a defendant can prove that he could not have fully premeditated a killing, he can use the defense to preclude a first-degree murder conviction. ${ }^{187}$ However, the same defendant has no claim in an assault or rape case because these are general intent crimes. ${ }^{188}$ Some states also restrict the use of the diminished capacity defense to crimes, which have "lesser-included-offenses;" therefore, negating mens rea for murder means that the individual could still be guilty of the lesserincluded offense of second-degree murder. ${ }^{189}$

While the genesis for such a narrow reading of the doctrine is not universally agreed upon, much like insanity, the appearance of the diminished capacity defense in high-profile cases seems to have chilled public and political support for the doctrine. In particular, the use of the defense in the 1979 murder trial of Dan White may have contributed to public backlash against the diminished capacity doctrine. In White's trial, despite his apparently cold-blooded killing of then San Francisco Mayor George Miscone and fellow Board of Supervisors member Harvey Milk, Dan White's diminished capacity minimized his penal consequences. ${ }^{190}$

$\S 25(a)$ (2010) (abolishing diminished capacity defense); Bethea v. United States, 365 A.2d 64, 89-90 (D.C. 1976) (same); Chestnut v. State, 538 So. 2d 820, 820 (Fla. 1989) (same); People v. Carpenter, 627 N.W.2d 276, 283 (Mich. 2001) (precluding evidence of mental abnormality to negate specific intent)

185 See Compton, supra note 182 , at $392 \mathrm{n} .96$ (citing cases).

186 See, e.g., State v. McVey, 376 N.W.2d 585, 588 n.l (lowa 1985) (listing over a dozen jurisdictions that limit diminished capacity defenses to specific intent crimes); see also People v. Guzikowski, No. 206947, 1999 Mich. App. LEXIS 2339, at *3 (Ct. App. Sept. 17, 1999) ("[D]iminished capacity is only a partial defense and it is only available in cases where the prosecution is required to prove a specific intent.").

187 See State v. Evans, 523 A.2d 1306, 1323 (Conn. 1987); Olsen v. State, 67 P.3d 536, 568 (Wyo. 2003).

188 A general intent crime "requires only that a defendant 'intend to do the act that the law proscribes." " United States v. Gonyea, 140 F.3d 649, 653 (6th Cir. 1998) (citations omitted).

189 See, e.g., McCarthy v. State, 372 A.2d 180, 182 (Del. 1977) ("[P]urpose of [a diminished capacity defense] is ... negating the requisite intent for a higher degree of the offense" to prove "that in fact a lesser degree of the offense was committed." (quoting C.T. Drechsler, Annotation, Comment note. - Mental or emotional condition as diminishing responsibility for crime, 22 A.L.R.3d 1228, 1238 (1968))); State v. Sessions, 645 P.2d 643, 644 (Utah 1982) (noting that " . . in most cases [diminished capacity] reduces a defendant's guilt to a lesser included offense which requires only a general intent").

190 Dressler, Understanding, supra note 155, at 347; Miguel A. Méndez, Diminished Capacity in California: Premature Reports of Its Demise, 3 STAN. L. \& POL'Y 
Limitations on the doctrine champion social control over individualized retribution, and they offer a clearly drawn line for efficient enforcement. But the line makes little sense if the underlying rationale for diminished capacity is that a defendant, while responsible for certain impermissible conduct, should be considered less culpable because of his mental disability. ${ }^{191}$ The application only to specific intent crimes or those that have lesser-included included offenses becomes arbitrary. ${ }^{192}$ The only real justification for such a limitation seems to be a concern that if defendants charged with general intent crimes can negate the mens rea element, the defendant might be exonerated altogether. This may be an untenable result from a social control standpoint, ${ }^{193}$ but it is the only outcome that is theoretically sound if there is to be any meaning to a state-of-mind requirement. ${ }^{194}$

The second, more serious problem with the existing diminished capacity doctrine is that even if diminished capacity permits evidence to negate mens rea in all crimes (as it does in Colorado), it still has limitations. ${ }^{195}$ The doctrine generally fails to account for the difference in culpability between defendants with mental retardation who demonstrate intent to commit a particular act (i.e., where the prosecutor could technically "prove" the element of mens rea), but are

Rev. 216, 218 (1991); John Rubin, Admin. Just., Memorandum: The Diminished CAPACITY DEFENSE 1 (1992). For a fascinating account of how the media distorted the diminished capacity defense in the case, see Carol Pogash, Myth of the 'Twinkie Defense': The Verdict in the Dan White Case Wasn't Based on his Ingestion of Junk Food, S.F. CHRON., Nov. 23, 2003, at Dl.

191 See, e.g., State v. Correra, 430 A.2d 1251, 1253 (R.I. 1981) ("A defendant claiming diminished capacity concedes his responsibility for the act but claims that, in light of his abnormal mental condition, he is less culpable.").

192 See Compton, supra note 182, at 392 (stating that "courts have given no logical answer to this dichotomy" of allowing evidence of mental abnormality to negate specific intent, but not general intent").

193 Stephen J. Morse, Undiminished Confusion in Diminished Capacity, 75 J. CRIM. L. \& CRIMINOLOGY 1, 13 (1984) [hereinafter Undiminished] (noting that "major argument" against use of diminished capacity defense is "that its adoption will endanger the public").

194 Courts have also justified limiting the diminished capacity defense as a way to distinguish it from the insanity defense. State v. McVey, 376 N.W.2d 585, 587 (lowa 1985). As the Colorado Supreme Court suggested in Hendershott v. People, 653 P.2d 385,394 (Colo. 1982), however, such an argument would suggest that legal sanity is a "proxy for mens rea," which it is not.

195 Approximately 15 states and the Model Penal Code allow for evidence of diminished capacity to be introduced to negate the mens rea of any crime. DRESSLER, UNDERSTANDING, supra note 155, at 369-70. 
less blameworthy, and other adults who do not have mental retardation. ${ }^{196}$

Negation of mens rea due to a mental abnormality is extremely rare, making the diminished capacity defense of limited utility. ${ }^{197}$ Thus, because of his disability, a person with mental retardation may react impulsively and excessively to provocation, may be goaded to act by a manipulative peer, may not realize his own strength or the boundaries of social interactions - but he may, all the same, "knowingly" or "purposefully" take a swing at another. ${ }^{198}$ It is not an accident or conduct based on a hallucination or a delusion. A diminished capacity defense would therefore offer no succor to the defendant charged with even aggravated assault, despite it being a specific intent crime with lesser-included offenses, if evidence existed that she had the requisite mens rea. The fact that she might have acted criminally only because of her mental retardation would not provide her any sort of legal cover or acknowledgment of her diminished culpability. These limitations render the current diminished capacity doctrine an interesting, but insufficient means for addressing cognitive difference in criminal law.

\section{B. Interstitial Perversions}

In lieu of legitimate doctrinal tools for addressing the wide swath of defendants with mental retardation who are not at the extremes of incompetency or insanity and who are unlikely to avail themselves of diminished capacity, defense counsel and courts must seek options outside the substantive criminal law. Sentencing is the most legitimate mop used to clean up what may otherwise be a mess of doctrinal

196 This is essentially what the court found in People v. Conley, 411 P.2d 911, 921 (Cal. 1966), where the panel overturned a first-degree murder conviction even though defendant met all elements, including the requisite mens rea, because he was not aware of a general obligation to act within the confines of society's laws. See also Stephen J. Morse, Diminished Capacity: A Moral and Legal Conundrum, 2 INT'L J.L. \& PsyChIATRY 271, 282 (1979) [hereinafter Diminished Capacity] (describing Conley court as "UJ]ustify[ingl a manslaughter instruction . . ." by ". . . impart[ing] independent meaning into the concept of malice aforethought."). Notably, the law in Conley is no longer valid. In 1981, the California legislature amended the state's definition of "malice," abrogating the rule in Conley (and its progeny) that implied malice encompasses a societal obligation, and rendering "express malice" and "an intent to kill unlawfully" functionally the same. See CaL. Penal CODE $\$ 188$ (West 2008).

197 See Arenella, Convicting, supra note 24, at 1524; Morse, Undiminished, supra note 193 , at $41-42$.

198 See Part ll for more extensive discussion of how mental retardation may affect criminality. 
injustice. But it is an imperfect instrument in many regards, and it does not prevent the initial spill. More problematic are tools such as juror nullification ${ }^{199}$ or unorthodox defenses. ${ }^{200}$ Such responses may threaten other criminal law pillars as advocates seek to address a defendant's mental retardation in a legal system, which largely deems the condition irrelevant.

\section{Sentencing}

Given the failings of the diminished capacity doctrine, some scholars and judges addressing cases in this area urge replacing diminished capacity with a sentencing scheme that can account for differences in culpability. ${ }^{201}$ Sentencing has the great advantage of being one of the few moments in the criminal process where decisionmakers are accustomed to individualized determinations, generally, and on the question of blameworthiness, specifically. ${ }^{202}$ As a result, it is the last, and most prominent bastion of culpability mitigation. ${ }^{203}$

199 Juror nullification "occurs when a jury — based on its own sense of justice or fairness refuses to follow the law and convict in a particular case even though the facts seem to allow no other conclusion but guilt." Jack B. Weinstein, Considering Jury "Nullification": When May and Should a Jury Reject the Law to Do Justice, 30 AM. CRIM. L. REv. 239, 239 (1993).

${ }^{200}$ For example, defense counsel might present the duress defense, which is notoriously difficult-to-prove, in situations where others have compelled her client to act, even where the basis for the defendant's conduct might not be objectively reasonable, or where she is precluded from introducing evidence of the defendant's mental retardation. See Steven J. Mulroy, The Duress Defense's Uncharted Terrain: Applying it to Murder, Felony Murder, and the Mentally Retarded Defendant, 43 SAN DIEGO L. Rev. 159, 167 (2006) (rejecting Sixth Circuit's exclusion of mental retardation evidence and use of objective standard in duress case of United States $v$. Johnson, 416 F.3d 464 (6th Cir. 2005)). Alternatively, defense counsel may present any defense which offers the defendant a chance to testify, simply so that jurors could observe any limitations for themselves.

201 See Peter Arenella, The Diminished Capacity and Diminished Responsibility Defenses: Two Children of a Doomed Marriage, 77 CoLUM. L. REV. 827, 848 (1977) [hereinafter Diminished]; Morse, Undiminished, supra note 193, at 25-28.

202 See, e.g., Arenella, Diminished, supra note 201, at 863-65 (explaining that courts are better able to tailor sentences to match culpability than juries); Gardner, supra note 34, at 748 (arguing that individualized determinations of defendant's "evil motive," background, and character is open-ended speculation better suited to competence of judges engaged in sentencing after determination of guilt has been made).

203 Judge Leventhal noted that "[t]he most that it is feasible to do with lesser disabilities is to accord them proper weight in sentencing." United States v. Moore, 486 F.2d 1139, 1180 (D.C. Cir. 1973) (Leventhal, J., concurring) (quoting MODEL PENAl CODE $\S 2.09 \mathrm{cmt}$. at 6 (Tentative Draft No. 10, 1960)). 
This is particularly true in the death penalty context, where mental disability is a required mitigation factor at sentencing. ${ }^{204}$ Some states also include mental retardation as a mitigating factor for sentencing purposes or exclude people with mental retardation from mandatory minimums. ${ }^{205}$ But even where state sentencing guidelines direct decision-makers to consider particular factors, the trial court has the discretion to determine the weight of any enhancement or mitigation. ${ }^{206}$ This ability to consider mental capacity as a mitigating factor does not translate into a mandate to do so.

Moreover, relying on a judge or jury's discretion - particularly unfettered discretion - does not guarantee that justice will be done. Indeed, there may be reason to fear that jurors, or even judges, will sentence more, rather than less, harshly because of the defendant's mental retardation if they have the option to do so. ${ }^{207}$ Some have even argued that people with mental retardation are over-represented in the criminal justice system because key players in the system, including judges and lawyers, are unsure how to "deal with this population in a professional manner." 208

Mandating a particular sentencing mitigation strategy based on mental retardation, however, would not solve the problem of diminished culpability among defendants with mental retardation. Sentencing is an after-the-fact way of ameliorating the unfairness of the current law; it still fails to allow defendants with mental

204 See Penry v. Lynaugh, 492 U.S. 302, 328 (1989). In the wake of Atkins, the Court has continued to emphasize that "impaired intellectual functioning is inherently mitigating," even in cases where there appears to be no nexus between the person's mental retardation and the offense. See Tennard v. Dretke, 542 U.S. 274, 287 (2004).

205 People v. Watters, 595 N.E.2d 1369 (1ll. App. Ct. 1992) (holding that trial court had discretion to disregard mandatory sentence of incarceration for sexual assault where defendant had IQ of about 60).

206 See State v. Blackstock, 19 S.W.3d 200, 211 (Tenn. 2000) (describing trial court's discretion to mitigate sentence by providing examples of statutory mitigating factors, including whether defendant's culpability was reduced due to mental or physical condition and whether unusual circumstances of offense show that intent was unlikely). Tennessee law requires judges determining a sentence to consider evidence offered in mitigation but does not mandate that particular factors be considered or particular weight be given to such factors. TENN. CODE ANN. §§ 40-35113, 210(b)(5) (West 1997).

207 See Atkins v. Virginia, 536 U.S. 304, 321 (2002) ("[R]eliance on mental retardation as a mitigating factor can be a two-edged sword that may enhance the likelihood that the aggravating factor of future dangerousness will be found by the jury.").

208 Jeffrey Schilit, The Mentally Retarded Offender and Criminal Justice Personnel, 46 EXCEPTIONAL CHILDREN 16, 19 (1979). 
retardation "doctrinal purchase" to argue for acquittal or mitigation. ${ }^{209}$ The consequences of a criminal conviction, including not only the sentence, but also the trauma of the process and the collateral consequences that may follow a conviction, cannot be undone because a judge or jury shows mercy on a defendant at the sentencing stage. As such, mitigation at sentencing will not sufficiently account for diminished culpability in individuals with mental retardation.

\section{Ad Hoc Defense Strategies}

The lack of a doctrinal avenue to legitimately introduce evidence of mental retardation during trial means that defense counsel sometimes must find other strategies for introducing facts about their client's disability to a jury, even if it means putting forth an inappropriate defense. An attorney may seek to put on an insanity, duress, entrapment, or other defense where the facts otherwise might not lend themselves to the theory simply because it gives him an opportunity to get the evidence of a client's mental capacity before the jury. For instance, to demonstrate that a client was more of a patsy or a victim of her co-defendant's manipulation, defense counsel might present a duress defense, even knowing that the high standard required of such a legal justification might be insurmountable. ${ }^{210}$ In essence, these lawyers seek juror nullification based on mental retardation because the law otherwise renders an individual's cognitive capacity largely irrelevant.

Jury nullification, a phenomenon where jurors deliberately disregard the law in rendering their verdict, ${ }^{211}$ may be one way to accurately reflect community standards of justice or distaste for the criminal

209 Stephen J. Morse, Diminished Rationality, Diminished Responsibility, 1 OHIO ST. J. CRIM. L. 289, 296 (2003) [hereinafter Diminished Rationality]. Identifying a similar problem, Morse proposes a "Guilty But Partially Responsible" verdict - if "defendant's capacity for rationality was substantially diminished at the time of the crime, and ... that ... diminished rationality substantially affected his or her criminal conduct." Id. at 299-300.

210 A duress defense generally requires that a person acted only because he was coerced to do so by threat of force or actual force and "a person of reasonable firmness in his situation" would have been unable to resist. MODEL PENAL CODE § 2.09(1) (2001). Because the standard of reasonableness is an objective one, a person with mental retardation might well have difficulty making the objective case that the defense requires, but his counsel might nonetheless assert the defense. See United States v. Johnson, 4l6 F.3d 464, 469 (6th Cir. 2005) (holding that "mental retardation is not part of [the] calculus" in determining whether defendant acted under duress).

211 BLACK'S LAW Dictionary 875 (8th ed. 2004). 
justice status quo, particularly as applied in a given case. ${ }^{212}$ However, this is not the most efficient way to manage the injustice of prosecuting those who lack culpability, and it may have unintended, pernicious effects. Lawyers are not permitted to encourage jurors to "nullify" the law directly. ${ }^{213}$ Moreover, some suggest that such nullification is an affront to the rule of law and the need for predictability in the criminal justice system. ${ }^{214}$ To the extent that people identify immorality or injustice in the criminal justice system, for instance, they may be less inclined to comply with the law themselves. ${ }^{215}$

More significantly, jury nullification is only available where judges actually permit counsel to introduce the evidence in the first place. Judge Jack B. Weinstein would have judges "exercise their discretion to allow nullification by flexibly applying the concepts of relevancy and prejudice and by admitting evidence bearing on moral values." However, few judges exercise their discretionary muscle in quite this way. ${ }^{216}$

Irreverent examples of zealous advocacy, including both novel defense theories and sentencing, remain insufficient, if creative, efforts to fill the lacunae left by traditional legal doctrines such as competency, insanity, and diminished capacity. Collectively, these legal responses outline the status quo for defendants with mental retardation. And collectively, they beg the question as to why the law disregards the challenges presented by so many defendants with mental retardation.

212 See, e.g., Paul Butler, Racially Based Jury Nullification: Black Power in the Criminal Justice System, 105 YALE L.J. 677, 680 (1995) (arguing that jury nullification is tool African-Americans should use to "prevent the application of one particularly destructive instrument of white supremacy - American criminal justice - to some African-American people); Jack B. Weinstein, The Role of Judges in a Government of, by, and for the People: Notes for the Fifty-Eighth Cardozo Lecture, 30 CARDOZO L. REV. 1, 121-22 (2008) (noting that jurors may nullify convictions where they believe law to be unjust or in conflict with their conscience).

213 Arie M. Rubenstein, Note, Verdicts of Conscience: Nullification and the Modern Jury Trial, 106 COLUM. L. REv. 959, 988 (2006) ("[A]rguing for nullification is forbidden by professional canons of ethics.").

214 Darryl K. Brown, Jury Nullification within the Rule of Law, 81 MINN. L. REV. $1149,1151-54$ (1997).

215 See Paul H. Robinson, Geoffrey P. Goodwin, \& Michael D. Reisig, The Disutility of Injustice, 85 N.Y.U. L. REV. 1940, 2013-15 (2010) (demonstrating empirically that "knowledge of systemic injustice can negatively affect not only compliance, but also other relevant variables such as cooperation and moral credibility").

216 Weinstein, supra note 199, at 241. 


\section{JUSTIFICATIONS FOR THE STATUS QUO}

The psychosocial and neuroimaging evidence makes it clear that people with mental retardation are not as blameworthy as other criminal defendants. So why does criminal have such restrictive ways of accounting for mental retardation? Put differently, why do policymakers - abetted by judges, prosecutors, and defense counsel - perpetuate the legal fiction that these individuals are equally culpable? While there are a number of potential explanations for the status quo, none suffices to justify the nearly wholesale rejection of bedrock principles underlying the doctrine of mens rea.

\section{A. Dangerousness and Social Control}

Preventing "dangerousness" may be the biggest concern of all; acknowledging differences in culpability means that at least some dangerous people will be free of legal consequences and supervision simply because of their mental retardation. The criminal law often seeks a difficult balance between social control and individual liberties, and the fear that a whole class of defendants could avoid taking (full) responsibility may tip the scales too heavily towards individual liberties. Indeed, some might argue that a person with mental retardation may be even more dangerous than an average offender. ${ }^{217}$ After all, releasing a person who has difficulty understanding norms and applying rules in new situations sounds like a recipe for recidivism. Nonetheless, other administrative and civil procedures could be used to accommodate this interest in incapacitation without compromising individual liberties through unfair, criminal punishment.

First, criminal law is about more than simply social control or management of undesirable conduct. For example, the law already identifies legal categories of people who cannot be subject to criminal processes and/or punishments, no matter how great the harm they have caused may be: the incompetent and the insane. Our discomfort with potentially absolving people from criminal responsibility explains

217 See, e.g., Atkins v. Virginia, 536 U.S. 304, 321 (2002) (noting that "reliance on mental retardation as a mitigating factor can be a two-edged sword that may enhance the likelihood that the aggravating factor of future dangerousness will be found by the jury"); Reid, supra note 107, at 22 ("Even when an attorney recognizes that mental retardation may legitimately mitigate his or her client's responsibility for the offense, it's difficult to convey that successfully to a jury."). But see Arenella, Diminished, supra note 201, at 857 (noting that "an offender's mental abnormality may be an aggravating, as well as a mitigating, factor if it makes him dangerous to society"). 
why we have limited application of these categories to extreme cases, namely, those who are very young and those who are very mentally impaired. ${ }^{218}$ However rare these categories may be, they offer a precedent of excluding certain people from criminal liability and sanctions all together.

The context of insanity and incompetency is also instructive because it provides a model for resolving some of those concerns related to the dangerousness of people in this marginal population. In most jurisdictions, when a court finds a person incompetent (and not likely to regain competency) or legally insane, the individual is not released to re-enter society. ${ }^{219}$ Rather, the person may be civilly committed (in the case of incompetency) ${ }^{220}$ or criminally committed (in the case of insanity) to the public mental health system. ${ }^{221}$ Whether an individual is committed through a civil process or as an automatic result of a criminal verdict, the commitment is meant to include supervision, treatment, rehabilitation, and/or training. This is theoretically designed to ensure that the person is not a danger to himself or others due to his mental condition. Commitment may be involuntary and may range from limited outpatient services to long-term inpatient care in a secure facility. This likely depends on the severity of both the person's condition and the likelihood of dangerousness. Such measures would seem to address some utilitarian concerns for safety of the community, up to and including the need for incapacitation and victim protection.

\section{B. Malingering}

Skeptics often raise concerns that certain legal benefits that might inure to people with mental disabilities should be used sparingly, if at all, due to the potential for fraud or malingering. ${ }^{222}$ However, expert evaluation can typically detect malingering. ${ }^{223}$ In particular, the mental

\footnotetext{
218 See Part III.A.1-2 for a more extensive overview and critique of the doctrines of incompetency and insanity, specifically with regard to defendants with mental retardation.

219 Wayne R. LaFave, 1 SubStantive Criminal LaW \$\$ 8.1, 8.4(a) (2d ed. 2011).

220 See Bruce J. Winick, Restructuring Competency to Stand Trial, 32 UCLA L. Rev. 921,933 (1985) ("Of those defendants found incompetent, the overwhelming majority are committed to state hospitals for treatment.").

221 See Jones v. United States, 463 U.S. 354, 366 (1983).

222 Atkins, 536 U.S. at 353 (Scalia, J., dissenting) (raising fear that Atkins decision will inspire legions of defendants to "feign" symptoms of mental retardation).

${ }^{223}$ See Steven J. Mulroy, The Duress Defense's Uncharted Terrain: Applying it to Murder, Felony Murder, and the Mentally Retarded Defendant, 43 SAN DIEGO L. REV. 159,
} 
retardation diagnosis requires not only IQ testing, but also ongoing impairment in at least two areas of adaptive functioning, and a record of onset prior to the eighteenth birthday. ${ }^{224}$ Chromosomal analysis, while not necessary for a diagnosis, may also help establish or confirm the diagnosis and, more specifically, its etiology. ${ }^{225}$

A "false negative" diagnosis of mental retardation likely occurs more frequently than a "false positive." That is, people with mental retardation tend to do everything possible to hide their disability or pass as a person of average intelligence. ${ }^{226}$ Thus, while policymakers may fear that people will fake their way out of legal responsibility, the bigger concern is those who actually inadvertently "fake" their way in. ${ }^{227}$ People with mental retardation, not necessarily cognizant of the severity of their situation, may not reveal their disability to parties like their counsel, who, in turn, may not be trained to identify the condition. Identifying mental retardation is also complex because a proper diagnosis requires the attentiveness and cooperation of defense counsel and others working with the defendant (such as family members, law enforcement, or court staff) to notice and potentially raise the issue with the court. ${ }^{228}$ The difficulty in successfully raising

195 (2006) ("Most experts testify that retardation cannot be feigned.").

${ }_{224}$ See Jonathan L. Bing, Protecting the Mentally Retarded from Capital Punishment: State Efforts Since Penry and Recommendations for the Future, 22 N.Y.U. REV. L. \& SoC. CHANGE 59, 89-93 (1996) (listing reasons there is no real risk of defendants faking mental retardation diagnosis, including need for early identification, need to demonstrate not only low IQ but impaired adaptive functioning, and procedural hurdles such as burden and standard of proof).

225 See Curry et al., supra note 6, at 468-72.

226 See Bonnie, supra note 15, at 423 (referring to "well-documented tendency of persons with mental retardation to conceal their disability"); Reid, supra note 107, at 20 (quoting mental retardation expert Ruth Luckasson's statement that people with mental retardation "would do anything to cover up the fact they were mentally retarded").

227 See Bing, supra note 224, at 90 (including defendant's interest in not being perceived as having mental retardation among reasons that malingering is unlikely issue).

228 See Appelbaum \& Appelbaum, supra note 11, at 483-84. These same parties may also have legitimate strategic reasons for not being forthright about a defendant's disability. In some cases, for instance, defense counsel may wish to conceal a client's mental disability to obtain a short sentence or other disposition rather than risk a longer term civil commitment based on a finding of incompetency. See James K. McAfee \& Michele Gural, Individuals with Mental Retardation and the Criminal Justice System, the View from the States' Attomeys General, in 26 Mental Retardation 5, 8 (1988); see also Wright Williams \& Jean Spruill, The Criminal Justice/Mental Health System and the Mentally Retarded, Mentally Ill Defendant, 25 SOC. SCI. MED. 1027, 103031 (1987) (finding that among defendants with mental illness found incompetent, those also diagnosed with mental retardation served more time incarcerated in 
the issue of mental retardation, based on the need for multi-party cooperation, the inclinations of the defendant, and the availability of tools to disprove false claims, contradict overblown fears of malingering.

\section{Administration}

Requiring a more intensive analysis of mens rea based on mental retardation also raises administrative issues, such as identifying population members and evaluating the diagnosis's effect on culpability. Differentiating individuals who have mental retardation from those who do not has become the first administrative concern in the wake of the Supreme Court's decision in Atkins, which involved the final penalty phase of trial. ${ }^{229}$ Assessing mental retardation at the outset of the criminal process raises additional procedural problems. ${ }^{230}$ Certainly, an official diagnosis of mental retardation includes extensive cognitive and adaptive testing by experts in mental retardation (not only by psychiatrists). ${ }^{231}$ Moreover, age of onset requirements may entail an investigation into school or other records to demonstrate manifestation of the disability prior to age eighteen. ${ }^{232}$ Finally, to the extent that the government contests the finding, the process can become even more complex and costly. ${ }^{233}$

In addition, there are a host of conceptual and diagnostic issues, which may lead to complex and costly litigation battles. Some of these issues have been raised in the Atkins aftermath. Who gets to decide the definition of mental retardation and what standard of proof will be required? What happens to a person whose IQ score puts her just over the line of mild mental retardation, but diagnosticians insist her adaptive impairments make a mental retardation diagnosis

hospitals/jails than their incompetent peers without mental retardation).

229 Weithorn, supra note 79, at 1203-04 (identifying difficulty in clinical and conceptual identification of mental retardation, and arguing that "the determination of which offenders fall within the protected group is deceivingly complex").

230 Kelly Christine Elmore, Note, Atkins v. Virginia: Death Penalty for the Mentally Retarded - Cruel and Unusual - The Crime, not the Punishment, 53 DePaul L. Rev. $1285,1338-39$ (2004).

231 James W. Ellis, Mental Retardation and the Death Penalty: A Guide to State Legislative Issues, 27 Mental \& Phys. Disabilities L. ReP. 11, 14 (2003) (detailing elements and expertise required for proper evaluation of mental retardation).

232 Penny J. White, Treated Differently in Life but not in Death: The Execution of the Intellectually Disabled after Atkins v. Virginia, 76 TENN. L. REv. 685, 709-10 (2009).

233 Weithorn, supra note 79 , at 1204 ("Much post-Atkins litigation has involved disputes about whether a particular defendant is or is not "mentally retarded."). 
appropriate? ? $^{234}$ What if the score is allegedly due to "the practice effect" or some other contestable phenomenon? ? $^{235}$

It would be naive to dismiss these potential issues and the costs and time needed to resolve them. But it would also be naive to think that concerns and litigation battles that arise in capital cases will replicate themselves with equal vigor in every non-capital case. This is particularly true where the political and public safety concerns are far less pronounced. People suspected of having mental disabilities are routinely screened for competency evaluations and may be given at least a tentative diagnosis of mental retardation at that time. ${ }^{236}$ In relatively minor cases, or cases where the mental retardation diagnosis is fairly apparent, prosecutors may well stipulate to such a finding.

The second administrative concern is determining precisely what significance a mental retardation diagnosis has for a person's culpability. In making his argument for a character-based system of culpability, which would allow defendants "to contest ... their status as blameworthy moral agents," Peter Arenella similarly recognizes that such a change could come with significant administrative (and other) costs. ${ }^{237}$ This concern may really boil down to a suspicion about the reliability of mental health testimony in general, particularly as it might result in "unjust" freedom for "dangerous" individuals. ${ }^{238}$ Psychiatry and psychology are not exact sciences, and a connection between a diagnosis and culpability is a particularly complicated endeavor. On the other hand, this is precisely the legal question that we ask judges and juries to consider whenever sanity is at issue. Such determinations are not beyond the reach of the whole criminal justice system.

None of these administrative concerns justifies ignoring the unfair prosecution and punishment of people with mental retardation. However, they should be factors considered in any proposal for change and do inform the proposal offered in Part V.

234 See Ellis, supra note 231 , at 13 (rejecting statutory reliance on particular IQ cutoff limits as "difficult to administer" despite their appeal for policymakers).

235 See Weithorn, supra note 79, at 1231 (describing the "practice effect" phenomenon as increased score that may occur when the subject has sat through a number of IQ exams and suggesting it, and other similar issues could affect who may be considered a person with mental retardation in post-Atkins litigation).

236 Moreover, some jurisdictions mandate that court-appointed competency evaluators have expertise in developmental disabilities. GARY B. MELTON ET AL., Psychological EVAluations For the COURTS 155 (Guilford Press 3d ed. 2007) (1987).

237 Arenella, Convicting, supra note 24, at 1616.

238 The government made a similar policy argument in its opposition to the application of a diminished capacity defense to non-specific intent crimes in Colorado. Hendershott v. People, 653 P.2d 385, 395 (Colo. 1982). 


\section{Prosecutorial Burden}

Another reason that we may disregard the disjuncture between culpability and criminal liability for these defendants is that doing otherwise might make the prosecutor's job too hard. The more the government needs to prove about a defendant's intent, the more difficult it is for prosecutors to indict a felony, to ensure that a defendant can be detained pretrial, or to prevail at trial. ${ }^{239}$ Eliminating the mens rea requirement, as is the case with strict liability crimes, is a prosecutorial piece of cake. ${ }^{240}$ By contrast, having to prove that a defendant with mental retardation meaningfully had intent - not just that he had the requisite "mens rea," but that he had the consciousness, choice, and control to be legitimately culpable for his conduct might untenably complicate the job of prosecutors and make it harder to secure convictions.

Critics argue that requiring proof of more complex mens rea requirements - anything beyond the Model Penal Code's "knowing" and "reckless" standards - is at best unnecessary and at worst impossible. ${ }^{241}$ Determining whether a person drove "willfully and maliciously" through a neighbor's fence, for instance, may require a complex examination of the person's motivation for his conduct, something that may be unknowable or unconscious. ${ }^{242}$ The Code defines culpability in relatively simple terms. ${ }^{243}$ It also provides basic procedural protections, including notice, efficient use of charging decisions, predictability of outcomes, and limited prosecutorial overreaching. ${ }^{244}$ Notably, however, the standard of proof rises as the defendant moves through the criminal process, from "probable cause" upon arrest ${ }^{245}$ to "beyond a reasonable doubt for conviction." 246 This

239 Cf. Laurie L. Levenson, Good Faith Defenses: Reshaping Strict Liability Crimes, 78 CORNELl L. REv. 401, 404 (1993) (noting that strict liability standard "affords both an efficient and nearly guaranteed way to convict defendants").

240 In the seminal case of Morissette v. United States, Justice Jackson acknowledged this prosecutorial advantage: "The purpose and obvious effect of doing away with the requirement of a guilty intent is to ease the prosecution's path to conviction, to strip the defendant of such benefit as he derived at common law from innocence of evil purpose, and to circumscribe the freedom heretofore allowed juries." 342 U.S. 246, 263 (1952).

${ }^{241}$ Gardner, supra note 34, at 652 (observing that before division between criminal and tort law, focus was on "compensating and buying off the feud" between parties, so law "likely paid little attention to niceties of culpability").

242 Id. at $714-15$

243 Model Penal CODE $\$ 2.02$ (1985).

244 Id. at 686-88.

245 Wong Sun v. United States, 371 U.S. 471, 479 (1963). 
gives the government time to build its case, and allows it some leeway to demonstrate the defendant's intent with weaker evidence in the early stages of the case.

Ultimately, ease of prosecution is only one criminal justice value. It must be weighed against a need to punish only blameworthy conduct. While culpability may be further "plumbed" in affirmative defenses and at sentencing, courts have been careful to preserve an initial culpability determination by including a mens rea requirement as the rule, rather than the exception, in the vast majority of criminal laws. ${ }^{247}$

\section{E. Net Widening}

We may also insist on maintaining the status quo because abandoning the traditional mens rea analysis will produce an overwhelming number of claims from people with a range of disabilities and other issues. ${ }^{248}$ This fear is not surprising. Any change in criminal practice or procedure potentially resulting in leniency will be subject to concerns about both floodgates and slippery slopes. If we apply more scrutiny to mens rea for people with mental retardation, for example, why not for those who act under the influence of drugs or alcohol, or for those suffering from mental illness? Indeed, in some jurisdictions, any of these conditions can serve as the basis for a diminished capacity defense precisely because these conditions compromise a person's thought processes.

Line drawing due to mental retardation, however, can limit this netwidening concern. Many jurisdictions preclude diminished capacity defenses based on intoxication, and we could similarly draw a bright line here to exclude people with what might be considered a selfimposed impairment. ${ }^{249}$ Another option is to distinguish between

${ }^{246}$ In re Winship, 397 U.S. 358, 364 (1970) (holding that Due Process Clause requires conviction only upon proof beyond reasonable doubt of every fact necessary to constitute crime charged).

247 See Staples v. United States, 511 U.S. 600, 605 (1994) ("[T] he existence of a mens rea is the rule of, rather than the exception to, the principles of Anglo-American criminal jurisprudence."(alteration in original) (citation omitted)).

248 See, e.g., Robert C. Topp, A Concept of Diminished Responsibility for Canadian Criminal Law, 33 U. ToRonto FAC. L. REV. 205, 213 (1975) (citing "fear that once the proverbial floodgates are opened, the courts will be deluged" with such pleas of diminished capacity).

249 See Morse, Diminished Rationality, supra note 209, at 300-01 (explaining that "voluntary ingestion of mind-altering substances, including ethanol (alcohol), is culpable" as opposed to a mental disorder, which is a "non-culpable" - and therefore mitigating - condition). Of course, addiction experts would counter that alcoholism or drug addiction is no more self-imposed than mental retardation or mental illness. 
mental retardation and mental illness, which is also fairly commonplace in both the medical and legal communities. A mental retardation diagnosis is multi-layered, hard to fake, and quite distinct from one for mental illness, even as the two conditions may commonly co-occur in the same individual. Tellingly, the common fear that eliminating the death penalty for people with mental retardation would result in a flood of petitions based on mental retardation has not been borne out. ${ }^{250}$ To the contrary, not only have courts been able to manage the claims, but a substantial number of them have been valid. ${ }^{251}$

\section{F. What Would We Do if We Knew?}

Perhaps the most cynical version of why we disregard the reduced culpability of defendants with mental retardation is that we simply lack a good alternative. If we determined, as we have with juveniles, that people with mental retardation were, as a class, less culpable, we would not have a particularly satisfying set of services or treatment plans to accommodate them in lieu of a prison or jail sentence. Prisons are inappropriate and dangerous placements for people with mental retardation, particularly because they are subject to more disciplinary infractions and abuse during incarceration. ${ }^{252}$ Moreover, rehabilitative services for this population are even less common than treatment for people with mental illnesses. ${ }^{253}$ But public mental hospitals, the most

See generally Alan I. Leshner, Addiction is a Brain Disease, and it Matters, 278 SCl. 45 (1997) (arguing that substance abuse is comparable to other chronic illnesses, with scientific bases, explanations, and treatment indicators rather than simply a social or moral problem).

250 See John H. Blume et al., An Empirical Look at Atkins v. Virginia and its Application in Capital Cases, 76 TENN. L. Rev. 625, 628 (2009) (finding that "Atkins has not opened floodgates of non-meritorious litigation," and noting that just $7 \%$ of death row inmates have filed Atkins claims).

251 See id. at 628-29 (noting that "nearly forty percent of all defendants who allege mental retardation have, in fact, proved it," a rate "substantially higher" than any other typical post-conviction claim).

${ }^{252}$ See Ellis \& Luckasson, supra note 4, at 479-80 (citation omitted) (acknowledging that mentally retarded prisoners receive more disciplinary infractions).

${ }^{253}$ Bertram S. Brown \& Thomas F. Courtless, The Mentally Retarded in Penal and Correctional Institutions, 124 AM. J. PsYCHIATRY 1164, 1164, 1169 (1968); Ellis \& Luckasson, supra note 4, at 480 (citing United States v. Masthers, 539 F.2d 721, 729 n.56 (D.C. Cir. 1976) (" [P]risons provide few, if any, meaningful programs or services for the retarded.")); Miles B. Santamour \& Bernadette West, The Mentally Retarded Offender: Presentation of the Facts and a Discussion of Issues, in THE RETARDED OFFENDER 7, 28-29 (Miles B. Santamour \& Patricia S. Watson eds., 1982). 
secure alternative for people found not guilty by reason of insanity, are often equally inappropriate. ${ }^{254}$ Unlike mental illness, mental retardation is not typically ameliorated with a regimen of medications. ${ }^{255}$

Civil commitment to a state's system for "training and rehabilitation" of people with mental retardation (as opposed to a public mental hospital) is the only option for state-imposed measures which can (even potentially) both protect the community and serve the needs of this population. The public mental retardation system has the advantage of targeting this population, rather than lumping them in with people who have no intellectual disabilities or people with mental illnesses. It also has a more appropriate theoretical basis. That is, civil commitment is purportedly geared toward protecting the safety of the community rather than imposing punishment for blameworthy conduct. ${ }^{256}$ It may be far from ideal to use the criminal justice system as a funnel into such an impoverished mental health services system, but at least it is a more appropriate forum to address a population that lacks the consciousness, choice, and control to be deemed criminally culpable. Ultimately, the justifications for the status quo do not outweigh the need to re-think criminal law's treatment of defendants with mental retardation. In the next Part, the article presents three options for how the criminal system might deal with

254 Reid, supra note 107, at 21 (explaining that in mental hospitals, "treatment is designed for the insane, not the retarded . . . Because the treatments offered in mental hospitals will have no effect, retarded persons end up warehoused indefinitely in inappropriate settings").

${ }^{255}$ The use of psychiatric medications among people with mental retardation is widespread and controversial. See J.A. Nottestad \& O.M. Linaker, Psychotropic Drug Use among People with Intellectual Disability before and after Deinstitutionalization, $47 \mathrm{~J}$. INTELL. DisABILITY RES. 464, 464 (2003). People with mental retardation may also have behavioral disorders, other mental illnesses, or maladaptive behaviors which may respond to treatment with psychopharmacological interventions. See Peter Sturmey, Diagnostic-Based Pharmacological Treatment of Behavior Disorders in Persons with Developmental Disabilities: A Review and a Decision-Making Typology, 16 RES. DEVElopmental Disabilities 235, 249 (1995). Literature addressing use and abuse of such medication for people with mental retardation, however, provides no indication that it will relieve all symptoms of the intellectual disability or increase IQ. See, e.g., William C. Torrey, Psychiatric Care of Adults with Developmental Disabilities and Mental Illness in the Community, 29 Community Mental Health J. 471 (1993) (indicating some appropriate uses of psychotropic medication for maladaptive behaviors or psychiatric symptoms in people with mental retardation without mentioning effect on IQ).

256 See Addington v. Texas, 441 U.S. 418, 428 (1979) (contrasting purpose of civil commitment proceeding "for the purpose of providing care" with "punitive" exercise of state power in criminal proceeding). 
these defendants. However, only one of these options directly addresses the problems created by the mens rea requirement.

\section{PROPOSALS}

If we abandon the myth that a showing of mens rea indicates actual culpability, we must re-think how the criminal law addresses adults with mental retardation. We have three choices: First, change the substantive law, so that mens rea requires a different, more specific showing of state-of-mind for defendants with mental retardation. Second, remove defendants with mental retardation from the jurisdiction of adult criminal court and address their conduct through a problem-solving court. Third, create a new doctrine that makes mental retardation relevant to the question of culpability. As set forth below, only the third option responds precisely to the prevailing myth of mens rea without creating an overly complex infrastructure or causing other untenable problems.

\section{A. Change the Substantive Law}

If the assumptions undergirding the use of mens rea as an indicia of culpability are valid for people of average intelligence, perhaps we can demonstrate that those assumptions are well-founded for a particular individual with mental retardation. For example, we could change the law of mens rea so that the government would bear the burden of showing that a person charged with arson has a capacity to understand his own actions, and social norms (consciousness); can make thoughtful and independent decisions (choice); and can control his conduct to a reasonable degree (control) - not just that he "purposely" set a fire. We could call this "mens rea illustrated," since it clarifies, rather than heightens, the usual narrow mens rea standard. Demonstrating the existence of mens rea illustrated could occur in a pretrial showing, out of the purview of the jury. If the government met its burden, it would only need to meet the traditional mens rea standard before the jury. But, if the government did not meet this initial burden, it could not prosecute the case as charged. Alternatively, the law could allow the jury to hear the expanded evidence with regard to mens rea.

Homicide cases in California used to follow the mens rea illustrated model where evidence was presented to the jury. To demonstrate the "malice" necessary for a first-degree murder conviction, the State had to show something akin to consciousness: that the defendant was aware of an obligation to act within the general body of the law 
regulating society at the time of the offense. ${ }^{257}$ Further, "deliberation" and "premeditation" - also required to prove a first-degree murder charge - mandated a showing analogous to "choice": that "the accused maturely and meaningfully reflect[ed] upon the gravity of his contemplated act." 258

This mens rea illustrated approach has multiple advantages. First and foremost, it addresses the underlying culpability gap because only those who were actually blameworthy would face criminalization for their actions. The questions it seeks to answer are not wholly unfamiliar to forensic experts. The "consciousness" and "control" questions, for example, find analogies in the cognitive and volitional prongs of the insanity test. ${ }^{259}$ This approach also treats people with mental retardation as individuals, acknowledging that some function at a much more sophisticated level than others. Because of this variation in capacity, some individuals could and should be subject to both the rewards and the challenges facing individuals without mental retardation, a possibility which mens rea illustrated allows. For developmental disability advocates, this so-called "dignity of risk," can be a key element of achieving community integration and the ideal of normalization. ${ }^{260}$ It means that a person with mental retardation can both get her day in court and be treated as an accountable person. ${ }^{261}$

On the other hand, mens rea illustrated raises problems of evidence and administration. First, there may be a difficult issue of proof, as lawmakers or courts seek to establish precisely what constitutes "consciousness," "choice," and "control," and whether each offense needs to individuate those terms. Even as the common law might eventually define these terms, demonstrating mens rea illustrated seems like it would require a potentially expensive expert battle for

257 People v. Conley, 411 P.2d 911, 918 (Cal. 1966).

258 People v. Wolff, 394 P.2d 959, 975 (Cal. 1964). However, as described above, the California legislature subsequently repealed these provisions in the wake of the Dan White case, narrowing the cognitive elements required for a first-degree murder conviction. See Méndez, supra note 190, at 221 (describing change of murder law in California after Dan White case, including unintended consequences of "simplifying" state-of-mind elements).

259 See supra Part III.A.

260 Robert Perske, The Dignity of Risk, reprinted in WOLF WOLFEnSBERGER, THE PRINCIPLe OF Normalization IN Human SeRVICEs 194, 194-95 (1972) (advocating opportunities for people with mental retardation to take risks commensurate with their functioning); see also WOLFENSBERGER, supra at 27 (arguing for "normalization," which urges maximum integration of people with mental retardation into conditions and norms of mainstream society).

261 Some have pointed to a similar "dignitarian rationale" underlying the doctrine of competency. See Bonnie, supra note 15, at 426-27. 
every case involving a defendant with mental retardation. To the extent that the jury hears expert testimony about mens rea, there may be concern that the expert(s) could inappropriately encroach on the jury's role in determining the question of whether the defendant had the requisite mens rea. Finally, mens rea illustrated disregards strict liability offenses, such as statutory rape, which do not have a mens rea requirement, but rely on a different set of assumptions for their validity. ${ }^{262}$

Unfortunately, the mens rea illustrated option may be too complex and expensive to administer across the board, especially for offenses as insignificant as misdemeanors, which constitute the vast majority of charges against people with mental retardation. ${ }^{263}$ In addition, prosecutors, judges, and lawmakers may have insurmountable political objections to the proposal, if charges (particularly serious ones) are dismissed when prosecutors fail to demonstrate mens rea illustrated. The backlash from the Harvey Milk/George Moscone murder is a potent reminder of the political risk in excusing apparently criminal conduct based on mental disabilities. ${ }^{264}$

\section{B. Create an Alternative Court}

A second proposal could require cases against defendants with mental retardation to proceed in a different kind of forum or court. The two nearest analogies in terms of alternative court systems are the juvenile justice system and the so-called "problem-solving courts," such as mental health courts. While these courts are an appealing alternative in some regards, the costs - in terms of dignity, administration, infrastructure, and overbreadth/judicial philosophy make this an imprecise fit for the problems presented in this paper.

The analogy to juvenile court for this population is obvious, yet placing people with mental retardation on a juvenile court docket is very problematic. That is, despite their chronological age of adulthood, people with mental retardation are often referred to by

262 See Nevins-Saunders, supra note 55, at 1081, 1113 (arguing that prosecutors should have to prove assumptions underlying strict liability i.e., that defendant understands both that people below certain age cannot legally consent to sexual activity and that particular complainant was underage).

263 William I. Gardner, Janice L. Graeber \& Susan J. Machkovitz, Treatment of Offenders with Mental Retardation, in TREATMENT OF OFFENDERS WITH MENTAL DisORDERS 329, 332 (Robert M. Wettstein ed., 1998).

${ }^{264}$ See Part III.A.3 for more on the political aftermath of this notorious use of the diminished capacity defense. 
their "mental age." 265 They are also routinely infantilized by parents, caregivers, and policymakers. ${ }^{266}$ It is, in part, this behavioral comparison that has led to legal comparisons. Analogies between children and adults with mental retardation have been made in areas such as competence ${ }^{267}$ and the death penalty. ${ }^{268} \mathrm{~A}$ natural extension of this comparison might suggest that adult defendants with mental retardation should be charged in juvenile court. After all, the juvenile justice system is partly premised on the idea that young people are not as blameworthy as adults. ${ }^{269}$ Perhaps adults with mental retardation should also be subjected to less punitive, less stigmatic, and more limited, rehabilitation-oriented proceedings with greater confidentiality and individualized treatment.

While this presents a compelling option, it ultimately fails on both theoretical and practical grounds. First, there are significant differences between people with mental retardation and juveniles. The notion of rehabilitation that underlies a juvenile court system - that young people can, with the proper supervision and services, reform and outgrow any criminal impulses - is not quite the same for adults with mental retardation. Indeed, while neuroscience research reveals that juveniles typically outgrow the impulse control and risk-seeking behaviors that make them less culpable than adults, ${ }^{270}$ there is no such

265 A "mental age" technically means that a person has an IQ score equivalent to what a typical person of a particular age might expect. Thus, an adult with a "mental age" of seven scored what a typical seven-year-old would score on the same test. Dorothy Griffiths, Sexuality and People Who Have Intellectual Disabilities, in A Comprehensive Guide to INTEllectual \& DeVelopmental Disabilities 573, 573 (Ivan Brown \& Maire Percy eds., 2007).

266 See Steven Reiss \& Betsey A. Benson, Awareness of Negative Social Conditions Among Mentally Retarded, Emotionally Disturbed Outpatients, 141 AM. J. PSYCHIATRY 88, 88-89 (1984) ("Retarded people tend to be treated like children long after they become adults.").

267 Ellis \& Luckasson, supra note 4 , at 417 (pointing to "the accepted analogy between the presumed incapacity of children and mentally retarded adults to form criminal intent").

268 See, e.g., Roper v. Simmons, 543 U.S. 551, 566-67, 575 (2005) (analogizing diminished culpability of people with mental retardation to diminished culpability of youth and finding analogy basis to constrain execution of individuals who committed crimes before age eighteen).

269 The exceptions, of course, are juveniles who have been removed to adult court, typically because they meet a certain age threshold and are charged with a sufficiently serious offense. M.A. Bortner, Traditional Rhetoric, Organizational Realities: Remand of Juveniles to Adult Court, 32 CRIME \& DelinQ. 53, 54 (1986).

270 See Elizabeth S. SCott \& LaURenCe D. Steinberg, Rethinking JuVEniLe JuStice 44-50 (2008); see also Mary Beckman, Crime, Culpability, and the Adolescent Brain, 305 SCl. 596, 596 (2004) (citing research that "the brain is still growing and maturing 
predictable change in the brain of an adult with mental retardation; they will never "outgrow" their condition. ${ }^{271}$ People with mental retardation can be trained to learn different skills and adaptive behaviors, but their capacity for development is more limited than it is for juveniles. The services and support necessary for this growth would also be completely different than what the juvenile population demands, exponentially expanding the range of services that courts and pretrial service agencies would need to employ.

Of course, the primary objection to treating people with mental retardation in juvenile court is that doing so this would infantilize and degrade this class of adults. Notwithstanding the common use - even in this Article - of the shorthand "mental age" of an adult with mental retardation, the convention is not necessarily an apt reflection of the individual's physical, emotional, and learning experiences. ${ }^{272}$ Segregating people with mental retardation into a separate system where they would enjoy fewer rights than other adult criminal defendants $\mathrm{s}^{273}$ could unnecessarily impinge integration efforts. ${ }^{274}$ Accordingly, disability advocates would not likely support such a proposal, and without their support, it would be nearly impossible to achieve such a dramatic policy and legal change.

The other option, sending this population to an adult "problem solving" court, overcomes the issue of infantilization, but raises other concerns. Most significantly, the theory behind problem-solving courts, such as drug or mental health courts, is that they solve "the problem" allegedly underlying a person's criminality. Examples of these allegedly criminogenic concerns include addiction or failure to obtain mental health treatment. ${ }^{275}$ But even assuming that the theory

during adolescence, beginning its final push around 16 or $17, "$ and continuing maturation until age 20 or 25 ).

271 See supra notes 6,160 and accompanying text (discussing permanency of mental retardation diagnosis and limited possibilities for cognitive development).

272 See Griffiths, supra note 265, at 573.

273 While In re Gault, 387 U.S. 1 (1967), made clear that juvenile defendants are entitled to certain key procedural protections enjoyed by their adult counterparts, there remain differences in the rights of juvenile versus adult defendants, such as entitlement to a jury trial. See McKeiver v. Pennsylvania, 403 U.S. 528, 544-45, 551 (1971) (acknowledging differences between adult and juvenile cases and denying juveniles right to jury trial).

${ }^{274}$ Garcia \& Steele, supra note 18, at $841-43$, 857-58 (rejecting use of juvenile justice philosophy equating adults with mental retardation and children otherwise completely segregates defendants with mental retardation from other adult defendants).

275 Bruce Winick, Therapeutic Jurisprudence and Problem Solving Courts, 30 FORDHAM URB. L. J. 1055, 1055 (2003). 
works for defendants in these other scenarios, how could one "solve" the "problem" of mental retardation? ${ }^{276}$ With constant training, management, or supervision, a person might learn, for instance, the difference between appropriate (legal) and inappropriate (illegal) sexual conduct. ${ }^{277}$ However, that growth is not certain, and such a lesson would need to be, like a mental retardation diagnosis, virtually lifelong - an impractical and expensive proposition likely to exceed the bounds of due process. ${ }^{278}$

To the extent that specialty courts have addressed the needs of defendants with mental retardation, they have done so in conjunction with mental health courts. ${ }^{279}$ This is risky because people with mental retardation often fare poorly when lumped together with people with mental illnesses. Their treatment regimes, providers, behaviors, and outcomes differ from people with mental illnesses. ${ }^{280}$ Further, the relatively small population of those with mental retardation (compared to those with mental illnesses) sometimes mean that their particular issues are not addressed when they are competing for the services and expertise of limited providers. ${ }^{281}$

Aside from dignity and administration issues, the principal problem with forum-based solutions is access. A specialty court promises repeat players and institutions, which means that a small set of judges, experts, and attorneys are likely to rotate through the court, developing useful knowledge and services more attuned to a particular population. But even assuming they become as widespread as other

276 Cf. President's New Freedom Comm'n on Mental Health, AChieving the Promise: Transforming Mental Health CARE IN AM. 1 (2003), available at http://store.samhsa.gov/shin/content/SMA03-3831/SMA03-3831.pdf (noting that "recovery from mental illness is now a real possibility").

277 AINSWORTH \& BAKER, supra note 90, at 97-103, 115-17 (emphasizing importance of sex education for this population).

278 See MONAT, supra note 108, at 28 (noting that process of sex education for even mildly mentally retarded adults "will take longer, need to be more concrete, and be a repetitive system of delivery of information").

279 See supra note 4 and accompanying text.

280 See Ellis \& Luckasson, supra note 4, at 423-25.

281 As explained in note 9, the number of people in prison and jail with mental retardation is unknown, but one survey of state and federal prison administrators reported that approximately $4.2 \%$ of their inmates were mentally retarded, and an additional $10.2 \%$ learning disabilities. Undisputedly, the number with mental illnesses is far greater. The Bureau of Justice Statistics has said $60 \%$ of jail inmates showed symptoms of a mental health disorder, followed by $49 \%$ of state prisoners and $40 \%$ of and federal prisoners. DORIS J. JAMES \& LAUREN E. GLAZE, U.S. DEP'T OF JUSTICE, SPECIAL RePort: MENTAl. Health Problems of PRison and JaIl InMATES 1 (2006), available at http://bjs.ojp.usdoj.gov/content/pub/pdf/mhppji.pdf. 
problem-solving courts, these "mental retardation" dockets are unlikely to reach many defendants, particularly those in smaller jurisdictions; based solely on geography, significant numbers of people with mental retardation would still have no policy or doctrinal relief for their unjust criminalization.

\section{Flip the Presumption}

The final option for dealing with defendants with mental retardation is flipping the mens rea presumption. If the problem with prosecuting defendants with mental retardation is the misplaced presumption of their culpability, then the most appropriate response may be a presumption that tilts in the opposite direction. That is, we should assume that this class of defendants cannot really be culpable and, therefore, cannot fulfill the requisite element of mens rea. As a consequence, charges against these defendants should be presumptively dismissed. Such a solution may be perceived as overbroad and unduly insensitive to disregarding another primary purpose of criminal law: public safety. Accordingly, prosecutors and courts could adopt a bifurcated response based on the dangerousness of the offense instead of relieving all defendants with mental retardation from all criminal liability.

Under a two-tiered approach, the presumption against culpability would apply only to those charged with nonviolent offenses. ${ }^{282}$ Under certain circumstances related to public safety, the government could overcome the presumption and proceed even in non-violent cases, as detailed below. For the most serious offenses, however, the individual could be tried and convicted as usual. ${ }^{283}$ However, the sentence would be limited to the least restrictive means necessary to secure the safety of the community. While such an approach is not a perfectly titrated response to the diminished culpability problem for this population, it

282 The actual fault line between the two types of offenses is likely to become a controversial political or judicial question, and I leave to others the task of making finer distinctions than the rough "violent non-violent" divide I have offered here. See, e.g., Jeff Bellin, Crime Severity Distinctions and the Fourth Amendment: Reassessing Reasonableness in a Changing World, 97 IOWA L. REV. 1, 22-34 (2011) (proposing strategy for classifying offenses into categories of severity in the context of the Fourth Amendment). Nonetheless, I draw this line recognizing that the presumption of nonculpability runs across all offenses. Accordingly, any countervailing argument must be both legitimate and narrowly tailored. If public safety is the justification for disregarding the lack of culpability among defendants with mental retardation, it should be at issue only in cases where a real threat to safety (i.e., violence) is alleged.

${ }^{283}$ In such cases, mental disability would remain a mitigating factor. See Penry v. Lynaugh, 492 U.S. 302, 328 (1989). 
balances concerns about convicting and punishing morally blameless individuals against concerns about public safety. ${ }^{284}$ This proposal also makes the most sense politically, administratively, and theoretically.

Procedurally, cases applying the 2-tier system would depend on a mix of cabined discretion and bright line rules. The bright line rules delineate to whom the doctrine would apply (defendants with mental retardation, unless the legislature or local rules expanded the target population), and for what offenses (violent versus non-violent). Beyond these baseline points, discretion, such as what would constitute a least restrictive penalty consistent with an explicit sentencing goal, would come into play. Some cases involving defendants with mental retardation who may not be truly culpable are already informally managed through prosecutorial charging decisions in the first place. ${ }^{285}$ This proposal would mandate that prosecutors engage in a more formalized, holistic approach to every case with a defendant reasonably known or suspected to have mental retardation. Where some indication exists that the individual may not have acted but for his mental retardation or may otherwise have been impaired due to his cognitive disability, the Government would act on its own to dismiss or decline to prosecute a case. To effectively make this determination, prosecutor offices would need to develop teams that specialize in mental retardation. ${ }^{286}$ Building this expertise is one way to ensure that the power of prosecutorial discretion is wielded effectively.

Resting with prosecutorial discretion, however, is far from a perfect solution, given the contrary incentives prosecutors face to assign blame and secure convictions. ${ }^{287}$ To counteract this possibility and to

\footnotetext{
${ }^{284}$ For instance, the proposal would not even presumptively dismiss the arson defendant. mentioned throughout this paper, given that the offense raises countervailing public safety concerns.

285 Scholars have acknowledged the phenomenon of courts using discretion to address mental retardation where doctrinal tools are not available. See Donald H.J. Hermann, Howard Singer \& Mary Roberts, Sentencing of the Mentally Retarded Criminal Defendant, 41 ARK. L. REV. 765, 789-90 (citing cases supporting claim that judges mitigate post-trial sentences for defendants who are willing to plead guilty but are "de facto incompeten[t]" to do so and, therefore, would otherwise miss out on sentencing benefit of guilty plea); see also sources cited supra notes 9,10 (showing other examples of parties using (and failing to use) discretion to address differences related to mental retardation that legal doctrine fails to account for).

${ }^{286}$ In smaller jurisdictions, such teams could be available regionally for consult with more dispersed or smaller offices.

287 See Smith, supra note 31, at 153 n.106 (quoting U.S. Department of Justice policy of seeking to charge and convict defendant of most serious offense, as well as maximum supportable sentence).
} 
accommodate the real possibility that defense counsel may be the first to recognize a defendant's intellectual disability, judges could also entertain a defendant's motion to dismiss based on mental retardation. As with questions of competency, such a motion, if contested, could invoke a pretrial hearing. ${ }^{288}$ Beyond establishing a person's diagnosis, the court could also entertain the government's argument for overcoming the presumptive dismissal.

To provide some structure for the court's decision (and to provide a framework for prosecutors considering discretionary decisions in these cases), courts could weigh a number of enumerated factors similar to those relevant under the Bail Reform Act for pretrial release. ${ }^{289}$ Considerations relating to a defendant's culpability and the need to begin or continue a prosecution could include: (1) community ties and support; (2) rehabilitative or supervisory programs in place; (3) nature and severity of cognitive disability and co-occurrence of other disabilities; (4) nature of the offense (particularly considering the alleged role of the defendant and his relationship to other parties involved); and (5) defendant's criminal history.

Assuming the Government has not decided sua sponte to forego prosecution, the defendant would have the burden to prove his mental retardation by a preponderance of the evidence. However, the burden to prove that the case should go forward, notwithstanding the relative insignificance of the charge, would fall on the prosecution. In other words, the presumption is that, where the defendant has mental retardation and the offense is nonviolent, the case will be dismissed.

There are a number of reasons that this bifurcated approach is the most appropriate resolution to the problems this Article discusses. First, and most obviously, this approach provides a comprehensive legal acknowledgment that a person's mental retardation may affect his criminality, even if it does not occur on the extremes of insanity or incompetency. Moreover, unlike sentencing, bifurcation addresses culpability at the front end of the criminal process, rather than presuming culpability with a criminal conviction and merely seeking to mitigate harm after the fact (and after the trauma of a trial) through a sentencing reduction. ${ }^{290}$ This solution provides the missing doctrinal

288 It is also possible that a culpability and competency hearing could be combined into one proceeding.

289 See 18 U.S.C. \& 3142(g) (2008). The Bail Reform Act ("BRA"), however, is hardly a perfect substitute for a more thoughtful list which is more closely tailored to the individual and his mental capacity than the very broad public safety concerns upon which the BRA focuses.

290 Much like competency, the issue of a person's mental retardation (and the 
hook that leads to the perversions of justice for people with mental retardation in the criminal justice system.

The proposal is also feasible. It would gain the support of advocates for people with mental retardation, who commonly seek human dignity and integration into the cultural mainstream. ${ }^{291}$ Unlike a juvenile court add-on or an absolute rule precluding criminal liability for individuals with mental retardation, it does not infantilize; rather, it preserves some "dignity of risk," without overstating the capacities or culpability of a vulnerable population. ${ }^{292}$ At the same time, it explicitly addresses public safety concerns, making it much more politically palatable to prosecutors, legislators, and other law enforcement-oriented policy-makers.

Administratively, the plan would be easier to implement than mens rea illustrated or developing an alternative court system. At its worst, the proposed system could engender a clash of experts over the diagnosis of mental retardation that would trigger its application. But, as noted in Part IV, assigning a bifurcated system lowers the stakes for the parties in most cases and, presumably, their thirst for battle.

Bifurcation is also consistent with sentencing justifications for people with mental retardation, including retributivism, deterrence, rehabilitation, and incapacitation. ${ }^{293}$ First, there is no retributive justification for punishing people who are not culpable. A fortiori, they do not deserve punishment. ${ }^{294}$ Second, prosecuting and sentencing people with mental retardation will not deter crime. As the Supreme Court stated in Atkins, these individuals are highly unlikely

according protections this proposal would offer him or her) could be raised at any point in the process, by any party with knowledge of the defendant's condition.

291 See WOLFENSBERGER, supra note 260 , at 45 (citing "maximal integration . . . into the societal mainstream" as "one of the major corollaries of the principle of normalization" for people with mental retardation and noting that "[o]ne major paradigm is to obtain services from generic agencies which serve the general public," rather than physically and socially segregating people with mental retardation into their own service providers).

292 See Denno, supra note 139, at 359 (articulating principle that there is no "dignity" in treating people with mental retardation "as though they possess capacities that they do not in fact have").

293 See Paul H. Robinson, Criminal Law: Case Studies \& Controversies 87-91 (2d ed. 2008) (explaining four primary purposes of punishment).

294 A retributivist theory of punishment has also been called a theory of "just deserts": "the retributive ideal" is that "offenders should suffer in proportion to their moral desert." Mary Sigler, Just Deserts, Prison Rape, and the Pleasing Fiction of Guideline Sentencing, 38 ARIz. ST. L.J. 561, 565 (2006). Thus, to the extent that there is no moral blameworthiness on the part of defendants with mental retardation, there should be no punishment based on retribution. 
to have the cognitive capacity to perform the cost-benefit risk analysis that underlies any effective deterrence-based strategy. ${ }^{295}$ Third, rehabilitation, another fundamental theory of punishment, is possible for people with mental retardation. As noted with regard to problemsolving courts, these individuals can be taught, educated, and trained, within certain limits. So it is conceivable that they could obtain support and services that would minimize the risk of future offenses. ${ }^{296}$ However, such rehabilitation would need to be specialized and ongoing to be effective since mental retardation is a persistent, lifelong condition. ${ }^{297}$ The high-level services necessary to such improvement are very unlikely to be available in a prison context. ${ }^{298}$

In most circumstances, then, we are left with incapacitation as the final justification for punishment. To the extent that a person is so violent that she poses a threat to the community, some might argue that culpability is irrelevant and that any distinctions based on mental capacity are insignificant. Despite the very real possibility that a person lacks blameworthiness, imposing criminal prosecution and, potentially, penalties, should not be taken lightly. Yet, allowing prosecutions to proceed in such instances is an acknowledgment of political reality and public safety.

Given the severity of consequences underlying the incapacitation justification, however, particularly for defendants with mental retardation (who routinely suffer more during incarceration than their counterparts of average intelligence), any criminal proceeding and subsequent sentence based on incapacitation should occur under the least restrictive means necessary to ensure the safety of the

295 Atkins v. Virginia, 536 U.S 304, 320 (2002). Not imposing criminal liability on defendants with mental retardation is also unlikely to deter criminal conduct of those who do not have mental retardation, as people of average intelligence would only assess their risk based on similarly situated individuals (i.e., those without mental retardation). Id.

296 See Ellis \& Luckasson, supra note 4, at 477 n.353 (citing R.L. Harbach, An Overview of Rehabilitation Altematives, in REHABILITATION AND THE RETARDED OFFENDER $122,132-35$ (P. Browning ed., 1976) ("[C]ommunity treatment centers reveal that community based corrections can serve as a practical alternative to conventional imprisonment.")).

297 See supra notes 6, 162 and accompanying text (discussing permanency of mental retardation diagnosis and limited possibilities for cognitive development).

298 This kind of programming is very unlikely to occur in any meaningful way in a prison setting, as correctional facilities have limited rehabilitative services and programs targeting people with mental retardation are virtually nonexistent. See Joan Petersilia, Prisoner Reentry: Public Safety and Reintegration Challenges, 81 PRISON J. 360, 361 (2001) (" $[\mathrm{T}]$ he corrections system retains few rehabilitation programs"). 
community. ${ }^{299}$ Supervision in a group home or placement in a secure mental health facility with appropriate habilitation services, for instance, may appropriately serve to incapacitate a defendant with mental retardation, without subjecting him or her to particularly inhumane treatment in a prison.

In some sense, this proposal, too, may be an overbroad response. It does not directly address the individual's culpability in a particular case. But as a response to what I have argued is an over-inclusive mens rea standard for more serious offenses, this proposal begins to reset the balance. Moreover, any overbreadth could compensate for the many other ways that a person's mental retardation affects her criminal outcomes in disproportionately negative ways. ${ }^{300}$

\section{CONCLUSION}

Culpability makes criminal law a moral venture, rather than simply a regulatory scheme. It is simply unjust to punish people who are not blameworthy. Criminal law, like Holmes's poor dog, has acknowledged the difference that intention makes. ${ }^{301}$ Accordingly, virtually all criminal cases require some form of culpability, a requirement typically imposed through the mens rea element. We can make this association between culpability and mens rea only because we presume that defendants have certain baseline capacities, to wit: an awareness of social and legal norms (and of their own conduct); an ability to reflect and make independent decisions about whether to comply with those norms; and an ability to execute those decisions thoughtfully, or otherwise restrain untoward impulses.

For defendants with mental retardation, however, the assumption that they have these underlying capacities is simply inapt. Decades of psychosocial research on this population demonstrate that members of this group do not have the consciousness, choice, and control that imbue a finding of mens rea with culpability. While scientists are just beginning to plumb the depths of neuroimaging information, this research tool also has begun to reveal evidence that these individuals are less culpable than people with average intelligence.

299 See supra note 11 and accompanying text.

300 See Atkins, 536 U.S. at 320-21 (noting "special risk of wrongful execution" for defendants with mental retardation because of increased likelihood of compelled confessions, diminished ability to assist counsel, difficulty serving as credible witnesses, etc.).

301 See Holmes, supra note 33, at 3. 
The fact that people with mental retardation are different from other criminal defendants has not gone totally unnoticed by criminal law. But frequently there is no doctrinal support for the introduction of evidence regarding this difference. This is particularly true outside the very porous sieves of the insanity, competency, and diminished capacity doctrines. Lacking viable alternatives, defendants may be compelled to take unorthodox measures to have courts consider the truly relevant information about their intellectual disabilities. While sentencing can remedy some of the doctrinal concerns related to people with mental retardation, there is no justifiable reason that a vulnerable population of defendants should have to be put through a traumatic process - especially one which wrongfully presumes their blameworthiness, convicts them, and saddles them with collateral consequences - just to have that conviction later "mitigated."

This Article proposes a solution that meets this doctrinal problem at its source. By flipping the inaccurate presumption of culpability attending the element of mens rea, it seeks to reverse the overbroad criminalization of people with mental retardation. While the flip enables us to dismiss nonviolent charges against this class of defendants, political and administrative concerns beg for a different result for those charged with violent offenses. In these more serious cases, defendants might be subject to normal criminal proceedings, but at least their sentences would be narrowly tailored to the least restrictive alternative to satisfy an express theory of punishment - a standard which does not typically apply to criminal dispositions.

It may seem like a radical proposal to presumptively dismiss a criminal case simply due to a person's diagnosis or mental health condition. But, given the research on people with mental retardation, and our theoretical and doctrinal tradition of holding only blameworthy people criminally accountable, it is the status quo that seems radical. We cannot refer to mens rea as a bedrock of criminal law if it fails so completely this population of defendants.

It is safe to say that a number of defendants - those with mental illness, head injuries, drug addictions, or even just irrational moments due to grief or trauma - might similarly believe that mens rea fails to adequately capture their culpability (or, more likely, lack thereof). Advocates for these populations may, therefore, seek to avail themselves of a doctrine that presumptively dismisses non-violent cases against their clients. Not all of these individuals are similarly situated, however. Those with brain injuries incurred in adulthood, for instance, may resemble people with mental retardation in every regard but for the fact that the onset of their condition occurred after age eighteen. At first blush, there would certainly seem to be no 
principled reason for treating members of the two groups differently. But more work will need to be done to assess whether the psychosocial and/or neurological evidence bears out this analogy. Even if it does, there may be political, administrative, or even theoretical differences that justify differential treatment for different classes of defendants.

In the end, we may question whether our current mens rea doctrine is an appropriate measure for a sufficiently large number of defendants to serve as the default rule. But whether we revise the doctrine in general or create additional carve-outs, it is critical not to charge, convict, or sentence defendants with mental retardation for offenses for which they are not truly culpable. 